\title{
DISCUSIONES CONTEMPORÁNEAS SOBRE DERECHOS HUMANOS EN EL MARCO DE LA GLOBALIZACIÓN
}

Maria Lucia Torres Villarreal

Paola Marcela Iregui Parra

-Editoras académicas-

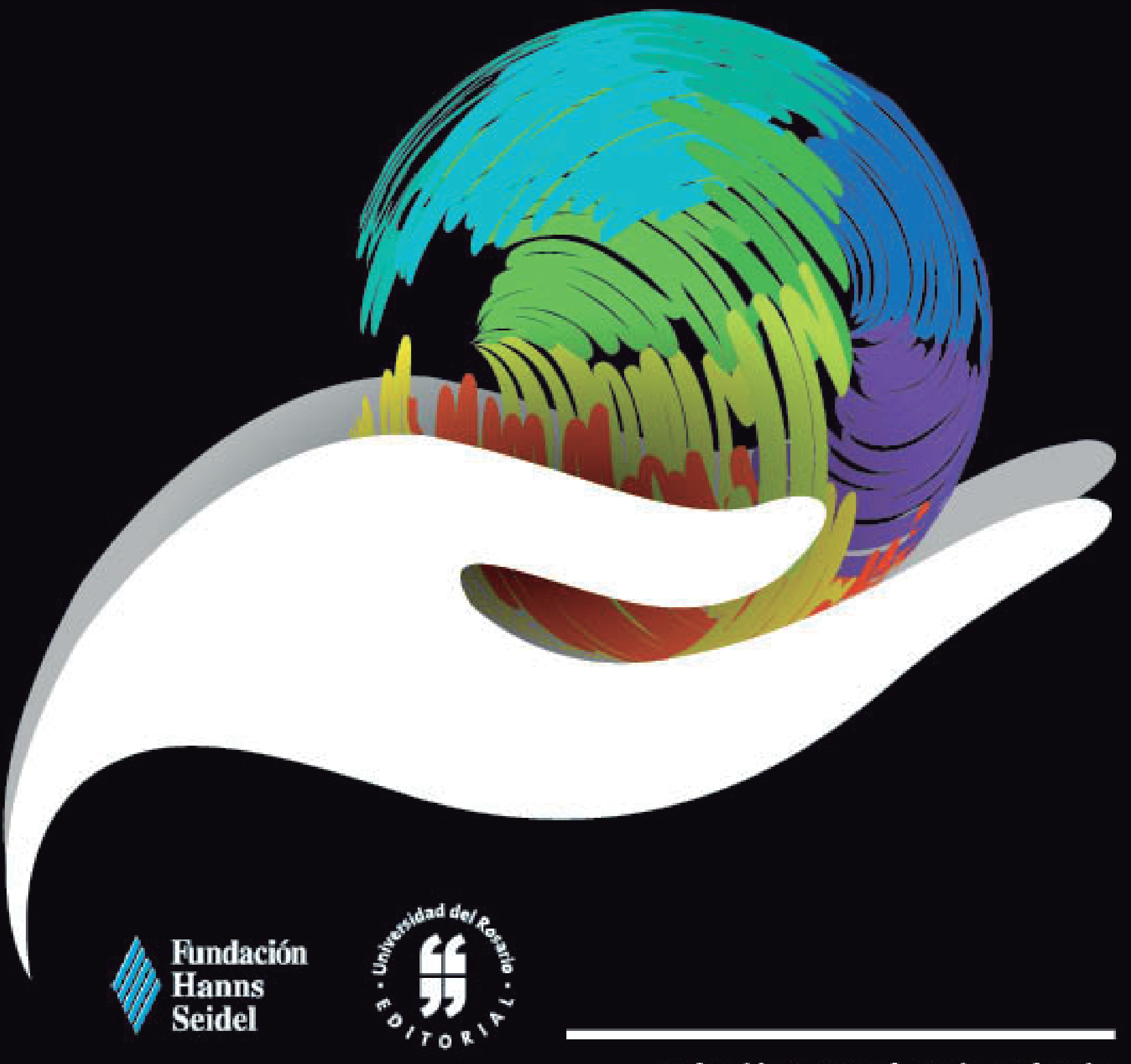



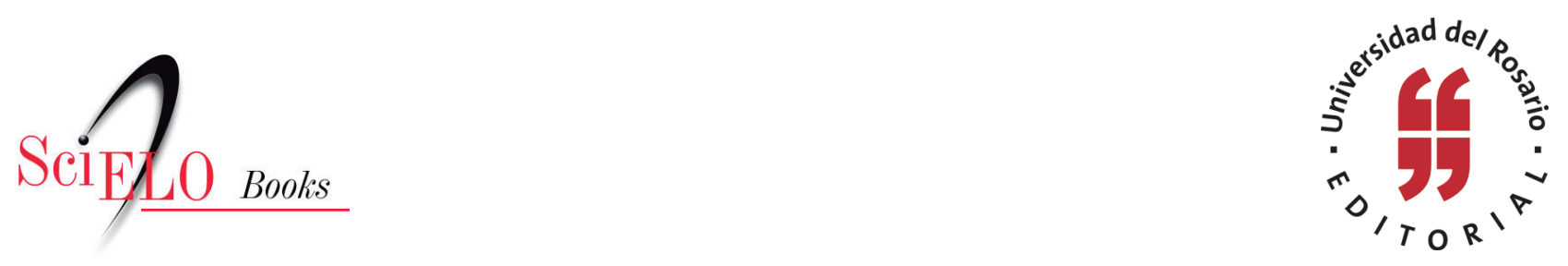

\title{
Discusiones contemporáneas sobre derechos humanos en el marco de la globalización
}

\author{
María Lucía Torres Villarreal \\ Paola Marcela Iregui Parra \\ (Editoras académicas)
}

MERCADO DONATO, M.A., and ROJAS PINZÓN, J.T. Desafíos conceptuales del bloque constitucional. In: TORRES VILLARREAL, M.L., and IREGUI PARRA, P.M., ed. Discusiones contemporáneas sobre derechos humanos en el marco de la globalización [online]. Bogotá: Editorial Universidad del Rosario, 2015, 87 p. ISBN: 978-958-738-671-4. https://doi.org/10.7476/9789587386714.

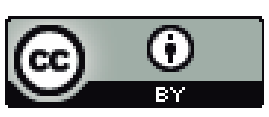

All the contents of this work, except where otherwise noted, is licensed under a Creative Commons Attribution 4.0 International license.

Todo o conteúdo deste trabalho, exceto quando houver ressalva, é publicado sob a licença Creative Commons Atribição $\underline{4.0}$.

Todo el contenido de esta obra, excepto donde se indique lo contrario, está bajo licencia de la licencia $\underline{\text { Creative }}$ Commons Reconocimento 4.0. 


\section{Fundación Hanns Seidel}

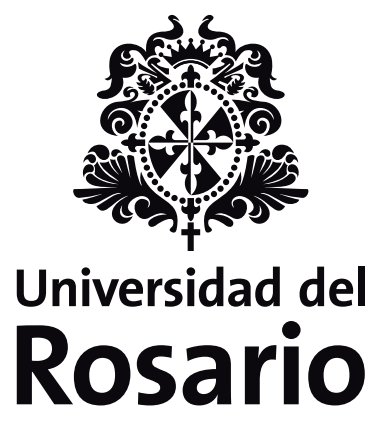





\section{Discusiones contemporáneas sobre derechos humanos en el marco de la globalización}


Discusiones contemporáneas sobre derechos humanos en el marco de la globalización / María Lucía Torres Villarreal, Paola Marcela Iregui Parra, editoras académicas. - Bogotá: Editorial Universidad del Rosario, Facultad de Jurisprudencia, 2015.

xi, 88 páginas. - (Colección Textos de Jurisprudencia, Serie Semilleros)

ISBN: 978-958-738-672-1 (impreso)

ISBN: 978-958-738-671-4 (digital)

Derechos humanos - Congresos, conferencias, etc. / Globalización - Congresos, conferencias, etc. / I. Torres Villarreal, María Lucía / II. Iregui Parra, Paola Marcela / III. Universidad del Rosario. Facultad de Jurisprudencia / IV.Título / V. Serie. 


\title{
Discusiones contemporáneas sobre derechos humanos en el marco de la globalización
}

\author{
María Lucía Torres Villarreal \\ Paola Marcela Iregui Parra \\ -Editoras académicas-
}




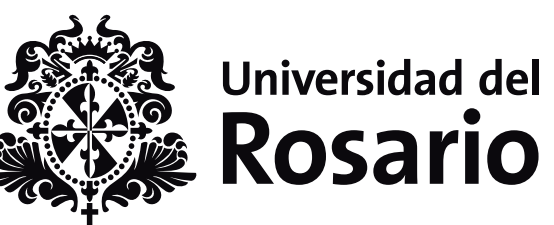

Colección Textos de Jurisprudencia

Serie Semilleros

(C) Editorial Universidad del Rosario

(C) Universidad del Rosario,

Facultad de Jurisprudencia

(C) Fundación Hanns Seidel

(C) Varios autores

Editorial Universidad del Rosario

Carrera 7 No. 12B-41, of. 501

Tel: 2970200

editorial.urosario.edu.co

\section{Fundación Hanns Seidel}

Primera edición: Bogotá D. C., octubre de 2015

ISBN: 978-958-738-672-1 (impreso)

ISBN: 978-958-738-671-4 (digital)

Coordinación editorial:

Editorial Universidad del Rosario

Corrección de estilo: Rodrigo Díaz Lozada

Diseño de cubierta: Kelly Narváez

Diagramación: Martha Echeverry

Impresión: Xpress. Estudio Gráfico y

Digital S. A.

Impreso y hecho en Colombia

Printed and made in Colombia

Fecha de evaluación: 16 de junio de 2015

Fecha de aceptación: 10 de agosto de 2015

Todos los derechos reservados. Esta obra no puede ser reproducida sin el permiso previo escrito de la Editorial Universidad del Rosario 


\section{Contenido}

Presentación................................................................... ix

María Lucía Torres Villarreal

y Paola Marcela Iregui Parra

Facultad de Jurisprudencia

Ponencia ganadora del primer puesto

Narrativas sobre construcciones de subjetividad

$\mathrm{y}$ autorreconocimiento indígena del pueblo nasa ............

Naidú Liney Sastoque Espitia

Fundación Universitaria Los Libertadores

Ponencia ganadora del Segundo Puesto

Derecho humano al agua en la comunidad wayúu

bajo la figura matrilineal................................................... 35

Melanie Vangrieken Alvarado

Universidad del Norte

Ponencia ganadora del tercer puesto

Desafíos conceptuales del bloque constitucional ............ $\quad 63$

María Alejandra Mercado Donato

y Julieth Tatiana Rojas Pinzón

Universidad de la Sabana 



\section{Presentación}

La coyuntura actual de Colombia con ocasión de las conversaciones de paz que desde hace casi tres años se realizan en $\mathrm{La}$ Habana entre el Gobierno y la guerrilla de las FARc, y la eventual entrada a un periodo de posconflicto, sumado a las tendencias internacionales en materia de protección de los derechos humanos, nos invitan como Academia a dirigir nuestra mirada sobre las discusiones contemporáneas alrededor de los derechos humanos en el marco de la globalización, evaluando los aportes que los Estados, los organismos internacionales y los expertos realizan constantemente en diversos temas, incluso antes impensables para la ciencia jurídica, pero que hoy ocupan lugares prioritarios en la agenda de los gobiernos y las organizaciones que propenden por la defensa de los derechos humanos.

Sobre esa base, la Universidad del Rosario, por conducto de su Grupo de Investigación en Derechos Humanos y su Observatorio Legislativo, en asocio con la Fundación Hanns Seidel, entendiendo la importancia que conlleva el hecho de que las nuevas generaciones se comprometan y desarrollen una opinión propia alrededor de temas de especial relevancia para el país, organizó la quinta versión del Concurso $\mathrm{Na}$ cional de Semilleros de Investigación, titulado "Discusiones 
contemporáneas sobre derechos humanos en el marco de la globalización”.

Estudiantes de cerca de veinte universidades, de programas de diversas áreas del conocimiento y provenientes de diferentes regiones del país, presentaron ponencias académicas de temas muy variados en relación con asuntos que ocupan las discusiones actuales en materia de derechos humanos, en un mundo que cada vez marcha más rápido, en el cual los derechos humanos deben ser parte integral de los avances legislativos, constitucionales, tanto en los asuntos internos de los Estados como en el marco de la comunidad internacional.

De las ponencias recibidas se seleccionaron veinticuatro para ser sustentadas en las rondas orales del Concurso, las cuales se realizaron en la Universidad del Rosario los días 19 y 20 de marzo del 2015. Las ponencias abordaban temáticas de diversa índole, relacionadas con comunidades indígenas, derecho internacional de los derechos humanos, responsabilidad de los Estados en relación con los derechos humanos y grupos de especial protección, entre otros temas.

Luego de las interesantes reflexiones propuestas en las exposiciones, obtuvieron los tres primeros lugares las ponencias: "Narrativas sobre construcciones de subjetividad y autorreconocimiento indígena del pueblo nasa. Un pueblo de ancestros, luchas y reivindicaciones", presentada por una estudiante de la Fundación Universitaria Los Libertadores (primer puesto); "El derecho humano al agua en la comunidad wayúu bajo la figura matrilineal", presentada por una estudiante de la Universidad del Norte (segundo puesto); “ "Desafíos conceptuales del bloque constitucional”, presentada por estudiantes de la Universidad de La Sabana (tercer puesto).

De tal forma, esta publicación compila las ponencias ganadoras de los tres primeros lugares, al igual que los cuatro 
libros que desde el año 2011 hemos venido publicando en el marco de la Colección Semilleros, la cual nace con el objeto de reunir los escritos de los estudiantes alrededor de temas de especial relevancia en materia de derechos humanos y que ameritan reflexiones juiciosas desde la Academia. La Fundación Hanns Seidel, desde el inicio, creyó en este proyecto como la forma de incentivar en las generaciones futuras la necesidad de investigar y analizar temas de interés público, necesarios en la construcción de una democracia sólida y garantista. En esta publicación, la número 5, queremos presentar un especial agradecimiento a la Fundación Hanns Seidel por respaldar esta iniciativa y por entender que desde la Academia se pueden gestar grandes cambios, cuando enseñamos a los estudiantes a investigar, a pensar y a sustentar sus opiniones con ideas sólidas y estructuradas.

La proyección social de la Constitución de 1991, la libertad de expresión, el proceso de paz, el desplazamiento forzado y las discusiones sobre las tendencias actuales de los derechos humanos, son los temas que a lo largo de estos cinco años han definido el Concurso y han permitido que los estudiantes fortalezcan sus criterios y habilidades investigativas. Esperamos una vez más haber cumplido con el objetivo de promover el desarrollo de nuevas ideas y propuestas en torno a temas que nos interesan a todos, que en últimas son los retos que tiene nuestro país en su deber de proteger los derechos humanos.

Bogotá, junio del 2015

María Lucía Torres Villarreal

Profesora de carrera académica

Facultad de Jurisprudencia
Paola Marcela Iregui Parra

Profesora de carrera académica

Facultad de Jurisprudencia 



\section{Narrativas sobre construcciones de subjetividad y autorreconocimiento indígena del pueblo nasa Un pueblo de ancestros, luchas y reivindicaciones Avance epistemológico y conceptual}

Naidú Liney Sastoque Espitia*

En este escrito se expone un avance en materia epistemológica y conceptual sobre el producto de semillero investigativo y la pasantía de investigación del proyecto Concepciones construidas por comunidades étnicas colombianas sobre la reparación integral como victimas del conflicto. Esto se soporta en el deseo de visibilizar, legitimar y tensionar las narrativas sobre subjetividad y autorreconocimiento del pueblo indígena colombiano nasa-paez, a través del análisis de los relatos de los actores del pueblo, contemplados desde un marco nacional de derechos

* Estudiante de X semestre de Psicología de la Fundación Universitaria Los Libertadores, semillerista de "Derechos Humanos y Minorías: Debates y retos en su implementación y eficacia de la Facultad de Derecho, Ciencias Políticas y Relaciones Internacionales”. Correo electrónico: nalisaes06@gmail.com 
humanos considerado como crítico, una historia imperante de violencia sociopolítica y una continua desacreditación de la indigenidad sobre los cánones de la vida occidental. De esta forma se rescatarán las narraciones sobre territorio, pertenencia y experiencia personal de ser indígena, propias de la construcción de subjetividades.

El proyecto está guiado bajo la directriz del socio-construccionismo y la psicología popular, con especial énfasis en los criterios de narración inteligible de Gergen y los rasgos de la narrativa de Jerome Bruner, para que mediante el dispositivo de las narrativas se esbocen los particulares matices de indigenismo de los nasas, se recreen escenarios de diálogo intercultural y se resignifiquen modos de acercamiento a las comunidades étnicas. Esto contribuye al conocimiento y a la visibilización del pueblo primigenio, sus procesos por autodefinirse y subjetivarse políticamente, especialmente en el escenario de la reparación. Asimismo, se busca invitar al debate a disciplinas afines con el fenómeno, garantizando la permanencia física y cultural de los pueblos y comunidades indígenas, a través de la divulgación de resultados y la invitación a discutirlos.

\section{Introducción}

En el momento neurálgico sociohistórico y político por el que atraviesa la Colombia del año 2015, con la negociación de paz con las farc (Fuerzas Armadas Revolucionarias de Colombia) — el acercamiento más significativo de las últimas décadas - resaltando las repercusiones en los procesos de significación y subjetivación que han tenido las nociones de violencia y guerra en la población colombiana durante poco más de medio siglo, y teniendo en cuenta que la situación de derechos humanos de nuestro país ha sido catalogada por la CIDH (Comisión Interamericana de Derechos Humanos) 
como "una de las más difíciles y graves de las Américas", se esboza un panorama de violación continua de derechos humanos en Colombia, especialmente para las comunidades y pueblos indígenas, donde todos y cada uno de los pueblos, según la onic (Organización Nacional Indígena de Colombia) están en riesgo de extinción física y cultural, debido a los efectos del conflicto armado interno, el modelo de desarrollo económico, la pobreza, la discriminación y el abandono institucional.

Con el reloj corriendo en contra de los colombianos cobijados bajo la Ley de Víctimas y Restitución de Tierras o Ley 1448 del 2011, que dicta las medidas de atención, asistencia y reparación integral a las víctimas, con la premisa de saldar una deuda moral con las víctimas, respaldado ello por el decreto-ley 4633 del 2011 — que dicta las medidas de asistencia, atención, reparación integral y de restitución de derechos territoriales a las víctimas pertenecientes a los pueblos y comunidades indígenas-, se hace visible un campo donde se hace estrictamente necesario el aporte disciplinar y profesional desde el marco de la psicología, para legitimar las voces de comunidades invisibilizadas, como los pueblos indígenas, en especial el pueblo nasa. Es allí donde nace el interés por estudiar el fenómeno de la subjetividad indígena de este pueblo primigenio, desde la categoría de las narrativas, con la finalidad de acercarse, en términos pragmáticos, a entender la diversidad étnica, la reconciliación, e invitar al debate a disciplinas afines con el fenómeno, como el derecho y la sociología, con el objetivo de co-construir el conocimiento y hacer un aporte a la acción psicosocial.

Lo hasta aquí señalado se basa en la situación actual del pueblo nasa, que ha sido continuamente relegado a ser una minoría, a ser invisible ante los ojos de los ciudadanos, y ello ha conllevado en muchos casos el olvido estatal y el prejuicio 
de una sociedad mayoritaria que naturaliza el desprestigio y el genocidio hacia lo indígena, que rechaza las actividades de su guardia indígena e impone sus estereotipos sociales sobre identidad y "maneras dignas de vivir" ante el fenómeno de subjetivación indígena de las nuevas y antiguas generaciones.

El pueblo nasa resistió por más de 150 años la fuerza destructiva de los conquistadores, en una guerra sangrienta en la cual la fuerza nasa buscaba evitar el exterminio de su pueblo. Para tal fin, se unificaron los cacicazgos en Tierradentro (Cauca), donde sobresalieron figuras como la cacica Gaitana y Juan Tama. Hacia 1650, la comunidad paez tuvo que aceptar algunos de los elementos culturales y el sistema que impuso la colonia para relacionarse con los 'blancos', razón por la cual tuvo de desaparecer la figura de los caciques y darle paso a los cabildos.

Dentro del horror que describen autores como Torodov en La Conquista de América, el problema del otro, hay una lucha y resistencia del pueblo paez, pueblo que además del atroz proceso de colonización, ha tenido que padecer los flagelos de medio siglo de conflicto armado colombiano, donde se han perpetuado y adaptado algunas de sus figuras, símbolos y prácticas. A título de ejemplo, el ser nasa se circunscribe dentro de un matiz de indigenismo particular, sin embargo, el prepararse y ser ratificado por la comunidad como kiwe thëgu (el que mira la tierra), es decir, un protector de la autonomía de la comunidad, dispuesto a defender la autoridad territorial, a proteger la tierra y contribuir a la preservación de la armonía y la unidad, tiene que ver con la conciencia de tener sentido propio, acorde a su identidad cultural, a la labor de alguacil o guardia indígena.

Como afirma la Cartilla del Resguardo Indígena Kwet Wala Dxüus Yat Nasa (Piedra Grande Casa Sagrada de los 
Nasa), "esta nueva estructura es de origen propio, soportada sobre nuestra propia Ley de Origen y nuestros principios, hace parte de nuestra búsqueda por autodefinirnos, y re-significar las funciones de nuestra comunidad desde nuestra propia identidad y cultura”. Es de esta forma que desde su lenguajear, sentir y actuar indígena, han transformado sus nociones y prácticas ancestrales para garantizar su pervivencia.

\section{El pueblo nasa-paez}

A continuación una breve contextualización sobre el pueblo nasa-paez o paez. Este es uno entre las variables cifras que datan el total de los pueblos indígenas colombianos, pues según la ONIC existen 102 pueblos, mientras que en los registros del DANe (Departamento Administrativo Nacional de Estadística), censo general del 2005, se encuentran 87 pueblos, con un número aproximado de 1'378 884 personas indígenas, 933800 asentadas en 710 resguardos existentes. En la disparidad de cifras se ven implicadas diferentes instituciones como la Dirección de Etnias del Ministerio del Interior y Justicia, el DNP (Departamento Nacional de Planeación), el Ministerio de Defensa y el DANE, lo que evidencia el desacuerdo nacional sobre el número total de pueblos, comunidades y personas que honran la diversidad étnica del país.

\section{Localización, demografía e historia}

Los nasas habitan a lo largo del sur de Colombia, en el departamento del Cauca se encuentra su territorio ancestral; sin embargo, hacen presencia en otros departamentos como Huila, Tolima, Meta, Putumayo, Caquetá y Valle del Cauca. Su población se estima en 360000 personas y se le considera el segundo pueblo indígena más numeroso de Colombia. De su historia se puede referir que el pueblo nasa creó sus resguardos 
indígenas a mediados del siglo xviıI, y en el siglo xx Quintín Lame lideró el movimiento indígena y consolidó el cabildo como autoridad. Este pueblo ha sido emblemático en materia de lucha y resistencia: asediado tras la fundación de Popayán, evangelizado por jesuitas y franciscanos, despojado de sus tierras por ganaderos, azotado por la violencia sociopolítica y los intereses particulares de organizaciones mineras, entre otros graves hechos.

\section{Mecanismos de autoabastecimiento}

Los paéces, o integrantes la comunidad nasa-paez, son un pueblo agrícola que se autoabastece, pues dentro de su mentalidad el ser nasa-paez implica ser un buen trabajador de la tierra. Uno de los ejes centrales en su cultivo es el maíz, tanto así que se habla de la "cultura del maíz". Su forma de trabajo representativa es el trabajo colectivo o minga, que permite que cada individuo aporte a la comunidad (Observatorio de Derechos Humanos y Derecho Internacional Humanitario [Observatorio de DDHн у DIH], 2010).

En esta línea de conservación de prácticas tradicionales, los nasas realizan labores artesanales, donde fabrican mochilas para uso cotidiano o venta; también elaboran una especie de cargador para los niños, denominado chumbe, y pequeñas mantas y cobijas de oveja; en ocasiones, también tejen sombreros de caña brava. Finalmente, la economía de este pueblo se basa en la agricultura (cultivo de maíz y laurel, que a su vez se utilizan en la medicina tradicional), la posesión y el cuidado de rebaños de ovejas, labor esta última que desempeñan las mujeres.

La fuente económica de las familias paeces es de base agrícola, la cual se combina con prácticas pecuarias, aunque en menor escala. Dentro de los productos que producen se encuentran: maíz, arracacha, yuca, plátano, fríjol cacha (silvestre), 
papa, habas, repollo, ullucos, cebolla, cilantro, chachafruto, caña de azúcar, pastos, ganado vacuno, porcino, ovino, caballar, pato, aves de corral, conejos, la mayoría de los cuales se orientan al autoconsumo. La base de la alimentación es el maíz (Pito, 2001).

\section{Lengua nativa o propia: nasa yuwe}

Los nasas poseen una lengua particular llamada nasa yuwe. Según el DNP (2010), 42,1\% del pueblo nasa-paez conserva su lengua, es decir, 78064 personas aún la hablan. Asimismo, "El páez o nasa yuwe (dicho en su idioma) aparece en varias clasificaciones como perteneciente a la familia chibcha, pero esta clasificación ha sido rechazada (Constenla, 1993). Por esta razón el paez con sus variantes, aparece como lengua aislada” (Sistema Información Indígena de Colombia [sıIc], 2009).

\section{Formas organizativas sociales y políticas}

A nivel político y organizativo, la figura principal del pueblo nasa es la Asociación de Cabildos del Norte del Cauca (ACIN), que a su vez hace parte del Consejo Regional Indígena del Cauca (CRIC) y de la Organización Nacional Indígena de Colombia (onic). La Acin o ACin cXab wala kiwe (Territorio del Gran Pueblo) nació en 1994 en Santander de Quilichao, con la intención de conformar una comunidad político-territorial y constituirse como territorio autónomo indígena, fortaleciendo al mismo tiempo las relaciones interétnicas, la armonía con la Madre Tierra y la participación política, económica y administrativa de la comunidad. Con estas pretensiones lograron agrupar diecinueve Cabildos y catorce resguardos indígenas de ocho municipios (Toribío, Caloto, Miranda, Corinto, Jambaló, Santander de Quilichao Buenos Aires y Suárez). 


\section{Cosmovisión}

La cosmología nasa tiene como elemento fundamental la casa yet, un espacio de construcción colectiva de la vida, metáfora construida a partir de su ley de origen, luego del llamado de los abuelos a los a los espíritus y vientos, invitándolos a cesar el daño; de esta forma los abuelos son los integradores del todo y los espíritus adquirieron cuerpo. Para estas comunidades así es el universo y de esta manera surgen las casas tanto de los animales como la casa de los nasas. Estas casas tienen corazón (fogón), ojos (ventanas), boca (puerta), costillas (paredes) y piernas (columnas). Está tan cimentada la idea primigenia sobre la casa como espacio de abrigo, que los principales héroes culturales se han destacado por defender su casa y su territorio, como Dxi'pam, el rostro del trueno.

Para el pueblo nasa, existen principios básicos por los que se orienta la vida, al cumplirlos se logra el estado final esperado: la armonía. El primero de estos principios es la espiritualidad (vivida a través de la relación con todos los seres, espíritus, fuerzas naturales y la comunidad presente en su territorio). El segundo está dirigido al uso respetuoso de la Madre Tierra, fuente de energía y vida, pues el territorio es la casa de abrigo, y por lo tanto se debe aplicar el "Tül”, un sistema tradicional de producción aborigen. Finalmente, la reciprocidad entre la comunidad, la tierra y la naturaleza debe fomentarse desde el trabajo comunitario (mingas), que establece el derecho a dar y recibir equitativamente sin causar daño o mal a otros, distribuyendo colectivamente los recursos, las oportunidades y la producción.

Dentro de los ámbitos ancestrales e intergeneracionales, una de las plantas más utilizadas por el pueblo nasa es la coca, la cual es vista como sagrada (Observatorio de DDHH y DIH, 2010). Pito (2001) sostiene que la medicina tradicional es 
celosamente conservada por los mayores, pues con el saber milenario el médico protege la vida de aquellas enfermedades culturales (el chamán establece que son provocadas por un duende de parcela, arcoíris, otro chamán, un desequilibrio espiritual, alteración de espacios sagrados por mujer menstruante, etc.) y naturales (producidas por accidentes, epidemias, parásitos, etc.). De igual forma, este personaje se encarga de limpiar los espacios para construir una vivienda, realizar limpiezas, "voltear" el mal a quien se vea afectado o ahuyentarlo.

En términos generales, los paeces han visto vulnerado su derecho a una integridad cultural y una identidad étnicacultural, porque las múltiples intrusiones de diferentes actores han ido en contravía de sus costumbres, acabando incluso con la transmisión generacional del nasa yuwe en los niños y jóvenes; por otro lado, dichos actores han privado a este grupo indígena del goce de un ambiente sano y ecológico. Es el caso de las empresas interesadas en la minería y los agrocombustibles, pues acaban con sus fuentes hídricas y van en detrimento del medio ambiente de la región.

Algunas instituciones estatales y empresarios han negado el derecho de los nasas al territorio, causando hacinamiento en los municipios donde se concentra este pueblo. Además, los grupos traficantes de drogas han establecido cultivos de coca, así como laboratorios y rutas para la cocaína, lo cual ha impactado al mismo tiempo las costumbres nativas, la concepción sobre el trabajo y las prácticas ancestrales de las nuevas generaciones, llegándose incluso a persuadir a los jóvenes para laborar en el ilícito.

La situación de conflicto armado no solo ha acabado con la vida de figuras fundamentales de la vida en comunidad, tales como profesores, líderes y guardias indígenas, sino que ha hecho cundir la sensación de inseguridad y que se viole la 
libre movilización por el territorio, con lo cual se ha afectado la vida digna, la autonomía política y organizativa, la seguridad alimentaria y el desplazamiento, con acciones como la siembra de minas antipersona, carros-bomba, enfrentamientos aéreos, etc. Estos hechos han sido divulgados por algunos medios de comunicación como la "muerte accidental de dos indígenas Nasa" o amenazas a veintiséis líderes de la comunidad perpetrada por actores armados de las FARC.

Aún quedan muchos otros hechos por esclarecer, como los ocurridos en abril del 2001 cuando un numeroso grupo de paramilitares del Bloque Calima amedrentó y asesinó a decenas de indígenas y afrodescendientes en la hacienda E1 Naya, hechos en los que la Unidad de Justicia y Paz estableció veinticinco víctimas mortales, mientras que la comunidad habla de aproximadamente cien personas fallecidas, muchas de ellos arrojadas al río Naya o lanzadas por abismos. ${ }^{2}$

Los nasas han sido insistentes en su exigencia al Gobierno nacional, organismos de control internacionales y ante los mismos actores armados al margen de la ley, de cesar los operativos militares en su región, recordando que los cubre el derecho internacional humanitario y reclamando a su vez el derecho a la autodeterminación como pueblo indígena,"a caminar sin temor de minas antipersonales, munición sin explotar, bombardeos aéreos o enfrentamientos":

1 Mayor información en http://www.eltiempo.com/politica/justicia/farc-diceque-muerte-de-indigenas-fue-un-error/14822437 y http://www.bluradio.com/81949/ milicianos-que-mataron-lideres-indigenas-en-cauca-fueron-presionados-farc

2 Mayor información en http://www.verdadabierta.com/lucha-por-latierra/5264-la-sangre-que-les-recupero-la-tierra-de-los-nasa 
No solamente sufrimos las consecuencias de la guerra, sino que se nos victimiza y además se nos señala y estigmatiza por los gobiernos nacional y departamental, y también, por las cúpulas y altos mandos militares. Esta situación nos coloca en alto riesgo y cuando se da una confrontación armada entre los actores del conflicto, nos vemos obligados a abandonar nuestras parcelas y cultivos y a pasar largos períodos sin alimentos. (Observatorio ADPI, s.f.)

He aquí una de las descripciones superficiales que relatan lo que sucede con las categorías que son materia de interés y estudio de este proyecto: el autorreconocimiento y la subjetividad indígena. Esta primera noción se encuentra directamente relacionada con la labor del psicólogo en contexto jurídico, pues pretende utilizar el saber disciplinar para, de y en el campo del derecho. Asimismo, se relaciona con categorías psicológicas, sociales y sociológicas como identidad y pertenencia, territorio, ancestralidad, victimización y vulnerabilidad.

\section{Subjetividad y autorreconocimiento}

El autorreconocimiento comprende la construcción de subjetividad y el entretejido de intersubjetividades, así como los procesos de empoderamiento en lucha y el mecanismo de resistencia de los pueblos. Como afirman Díaz y González (2005), la subjetividad está mucho más allá de ser una "no objetividad", somos sujetos en proceso, no se trata de influencias que de forma inmediata, directa, unilineal, hayan configurado nuestra subjetividad, sino de "recortes, consecuencias y episodios aislados de esas experiencias las que, a través de la forma en que las vivimos, definen nuestra organización" (p.6).

Los citados autores plantean una subjetividad anclada en una perspectiva histórico-social abanderada por autores como 
Vygotsky, idea que mantiene la línea de coherencia interna y establece un punto de cohesión con los otros autores a los que acudimos con la categoría narrativa, es decir, Bruner y Gergen. Para Díaz y González (2005) existen múltiples conceptos que intervienen en la discusión como lo son subjetividad social, subjetivación, subjetividad individual y subjetividad política, entre otros. A continuación un breve recuento sobre las nociones trabajadas por estos psicólogos, colombiano y cubano, (Díaz y González, 2005): en primer lugar, "la subjetividad se forma socialmente, pero no es la 'suma objetiva' de lo vivido: representa una producción arbitraria y distorsionada de la experiencia que se produce a partir de un momento real o imaginario en que un espacio de esa experiencia se carga de emocionalidad y se desdobla en múltiples alternativas simbólicas"(p. 11).

Desde la perspectiva del renombrado psicólogo cubano Fernando González Rey, hay una complejidad que debe reconocerse desde la psicología, complejidad que a manera de símil acaba por ser un molde constituido socialmente: "el hombre se produce sobre/ desde/ dentro de lo social [...] La subjetivad social no es una antropomorfización de lo social es el proceso subjetivo cargado de sentidos y procesos simbólicos que se desdoblan entre un conjunto de figuras sociales $[. .$.$] creo la$ subjetivación es el proceso mediante el cual permanentemente se da esa integración simultánea entre los espacios individual y social" (p.9).

\section{Algunas consideraciones sobre el proyecto}

Así como se viene dilucidando esta multiplicidad de procesos relativos a la subjetividad que ocurren alrededor de lo social, individual, emocional y psíquico, de igual forma, la autora de este proyecto considera que posiblemente el proceso de reparación 
integral dentro del que está enmarcado el proyecto de investigación Concepciones construidas por comunidades étnicas colombianas sobre la reparación integral como víctimas del conflicto, en su primera fase, de consulta previa y concordancia con el enfoque diferencial, puede potenciar o ir en detrimento de la construcción y reivindicación de la subjetividad diferencial. Finalmente, en la segunda fase se pretende analizar las narraciones sobre dichas categorías, para develar descripciones densas que hermenéuticamente intentan trabajar sobre el sentido y el significado de lo que se narra, porque como sostienen Díaz y González (2005):

[...] la subjetividad política es un momento de una subjetividad social [...] Porque cuando hablamos de subjetividad política, en ella, está la religión, están las creencias, están los mitos [...] están una cantidad de cosas que en sentido estricto no forman parte de la actividad de la organización política. Esa subjetividad política son síntesis de una subjetividad social con desdoblamientos infinitos, de allí que me cuesta trabajo seccionar la subjetividad, decir que esto es dominio de la subjetividad política. (p. 13)

\section{Reparación: un concepto que transita entre la psicología y el derecho}

El lector se preguntará el porqué del título de este aparte, pues el concepto reparación, en el que trasciende la acción psicosocial del presente proyecto, está cimentado en la noción simbólica, de la que se ocupa la psicología. Esto se expone ampliamente a continuación.

La reparación simbólica, concepto trabajado por Guilis (2005), parte de utilizar los conceptos del derecho para la práctica psicojurídica, entendiendo el reto que supone tal propósito en materia de significados y visiones epistémicas y sus 
incidencias en la subjetividad. La reparación no debe ser vista como la imposición de una cuota de dolor que corresponda al dolor causado, antes bien debe apuntar a producir subjetivamente en la víctima el desmantelamiento de las condiciones que produjeron el trauma/dolor. El concepto entonces no debe estar direccionado solo por las nociones de lo justo, sino también por las de bien o bueno.

Según la onu (citada por Guilis, 2005), las víctimas, en todos los niveles, tienen el derecho a ser reparadas por todos los daños y perjuicios producidos. Este derecho se despliega en: restitución (retorno a la situación antes del daño), indemnización (cubriendo los daños psíquicos, físicos, morales, pérdida de oportunidades, entre otros) y rehabilitación (tipo médico, psicológico, psiquiátrico o activación de redes). En este orden de ideas, la autora reconoce que los propósitos que se plantean, en especial la recuperación de la situación previa al daño, presentan un posible simbólico, tras la imposibilidad material. En este lugar de lo simbólico, donde tiene cabida la reparación, es imprescindible involucrar la subjetividad del afectado y su connotación sobre el concepto de reparación.

Ahondando en el ámbito simbólico, es necesario remitirse a la genealogía psicológica de la reparación. En este sentido, Guilis (2005) reconoce a Melanie Klein como la pionera en utilizar el término en la disciplina, aludiendo a un mecanismo intrapsíquico, mientras que para la visión jurídica obedece al plano de lo externo. El carácter simbólico se matiza en dos puntos neurálgicos: el primero de ellos hace referencia a que la reparación es simbólica, siempre que sea una representación (cualitativa o cuantitativa) de aquello que se ha perdido o flagelado, y nunca lo dañado en sí mismo, pues se persigue un imposible cuando la pretensión es resarcir la totalidad de 
los perjuicios, por lo cual se aproxima en mayor medida al acto de justicia que al de restitución.

En segunda instancia, la reparación se hace simbólica en la medida que está completamente expuesta al proceso de significación que la víctima le otorgue a lo perdido y lo ofrecido por la reparación, abriéndose con ello el panorama a un proceso único, íntimo y singular en el trabajo de simbolización: "el símbolo (reparación) no mantiene con lo simbolizado (aquello que se ha perdido y cuya pérdida debe repararse) una relación unívoca y fija" (Guilis, 2005, p. 97); por el contrario, el sujeto afectado está continuamente modelando el símbolo, y lo que este representa no será una cosa, sino la recomposición que el psiquismo logra hacer de lo perjudicado.

En esta visión, es necesario distinguir entre el acto reparatorio y la reparación. El primero se lleva a cabo en el proceso de justicia, donde el que ha dañado está obligado a reparar; sin embargo, los efectos reparatorios corresponden al orden psíquico de la víctima, lo que reivindica su autonomía psicológica, evitándose la idea de que el gesto que pretende reparar, en realidad produce tal efecto y hay otro pretendiendo dominar o someter su psiquismo a un efecto particular.

La reparación implica pensar en qué se puede reparar, tras definir claramente qué fue lo perjudicado. En este sentido, se distinguen el daño moral y el daño psíquico, el que se inflige al sujeto jurídico (corte universalizante) y el que tiene en cuenta la dimensión subjetiva que afecta el uso de las potencialidades y recursos (corte singular). Esto hace que el daño moral sea cercano a la indemnización y que el daño psíquico requiera otros esfuerzos, pues reconoce la concepción del acto reparatorio por parte de la víctima, sin olvidar que en la justicia debe apaciguarse su dolor, pues "el acto de justicia, la definición de las responsabilidades y la aplicación de la pena correspondiente, 
son en sí mismos actos reparatorios"(Guilis, 2005, p. 112). Dichos actos no pretenden retornar a un estado, sino devolver la característica de espacio habitable a la vida social de la víctima.

Por otra parte, las leyes de reparación económica en materia de indemnización incluyen el reconocimiento del hecho por parte del Estado, la verdad de los hechos y la aplicación de la pena correspondiente. Finalmente, Guilis (2005) dilucida cómo hay un concepto de compleja definición y difícil consenso que intermedia todo lo hasta aquí dicho: el de dignidad.

América Latina es considerada uno de los espacios geográficos en donde se han acentuado en mayor medida los procesos de desaparición forzada, los cuales, lamentablemente, se vieron sustentados por un marco político e ideológico. En Colombia hubo el atenuante de que las más altas cifras de desaparición forzada se registraron durante gobiernos elegidos democráticamente, mientras que en países como Chile este fenómeno se dio en la búsqueda del restablecimiento de la democracia. En este contexto, emerge la imperiosa necesidad de la intervención psicosocial del profesional en psicología, ahondando en los aspectos éticos, teóricos y procedimentales, y por lo tanto se requiere revisar la noción de trauma (Bravo, 2011).

Bravo se basa en el aspecto eminentemente psicosocial del trauma, distinguido por Martín Baró (retomado por Bravo, 2011) y su elemento dialéctico, en donde el sujeto está vinculado a un sistema de relaciones que ha de ser tenido en cuenta para la superación, evitándose con ello mantener las condiciones sociales que produjeron el hecho.

Bravo (2011) cita a González, teniendo en cuenta su particular perspectiva en el reconocimiento del sentido subjetivo dado por la unidad de los procesos simbólicos y emocionales, que en este caso no contribuyen al procesamiento adaptativo de lo sucedido. El autor llega a la conclusión de que la reparación 
integral debe esclarecer tanto la forma de producción del hecho, la escala de responsabilidades y el reconocimiento de las víctimas como actores activos del proceso, con voz propia y en capacidad de empoderarse nuevamente de sus derechos.

\section{Metodología}

Se pretende identificar las narrativas de daño, violencia, vulnerabilidad, conflicto, identidad, indigenismo y territorio que esbozan la narrativa de subjetividad de los actores del pueblo indígena nasa, por medio del análisis sistemático de la recolección de relatos realizada por los profesionales, técnicos y enlaces étnicos de la Unidad de Atención y Reparación Integral a Víctimas (UARIV), entidad que apoya el proyecto de investigación Reparación integral con comunidades y pueblos indigenas de Colombia: retos y perspectivas en escenarios de construcción de paz.

Posteriormente, se pretende codificar la información por medio de una matriz de integración, a través de unidades de análisis o categorías, como productos de la integración con la información encontrada en la investigación y con los fundamentos teóricos, en este caso los criterios de narración inteligible de Gergen y los rasgos de la narrativa de Jerome Bruner. Por último, se condensan como etiquetas categoriales elaboradas y complejas, entretejidas con la cosmovisión del pueblo y la comunidad indígena a la que se alude.

Desde la postura hermenéutica adoptada por la psicología popular de Bruner, se intentará lo que los investigadores cualitativos han denominado un proceso de "artesanía intelectual”, que dilucide las descripciones de cada categoría encontrada en los metarrelatos sobre reparación y las relaciones entre categorías. Estas últimas deben contribuir a una aproximación sobre las prácticas, cosmovisiones y expectativas 
de las comunidades indígenas sobre la reparación en un marco de reparación integral, y asimismo, desde la disciplina psicológica, a la permanencia física y cultural de los pueblos y comunidades indígenas, a través de la divulgación de resultados y la invitación a su discusión.

\section{Resultados parciales}

A continuación se expondrán los marcos de referencia tenidos en cuenta para la consolidación de la primera fase del proyecto de pasantía de investigación, la cual básicamente afianza la visión epistemológica, conceptual y categorial del proyecto.

\section{Marcos de referencia}

Estos son el marco jurídico y el marco disciplinar.

\section{Marco jurídico}

En primer lugar, la Ley 89 de 1890, "Por la cual se determina la manera como deben ser gobernados los salvajes que vayan reduciéndose a la vida civilizada", regulaba los cabildos y resguardos indígenas. Luego, con el advenimiento del Convenio 169 de la oit (Organización Internacional del Trabajo) en 1989, Colombia asumió la responsabilidad de desarrollar una acción coordinada y sistemática para proteger el derecho de los pueblos y garantizar el respeto a su integridad. Este convenio fue ratificado por la Ley 21 de 1991,y ese mismo año la nueva Constitución Política introdujo artículos que destacan el carácter pluriétnico de la nación; entre estos se destacan:

- "El Estado colombiano reconoce y protege la diversidad étnica y cultural de la Nación Colombiana"(Art.7).

- “... las lenguas y dialectos de los grupos étnicos son también oficiales en sus territorios. La enseñanza 
que se imparte en las comunidades con tradiciones lingüísticas propias, será bilingüe”(Art. 10).

- “... todas las personas gozan de derechos, libertades y oportunidades sin ninguna discriminación por razones de sexo, raza, origen, lengua, religión"(Art.13).

- "Las tierras de resguardo [...] son inalienables, imprescriptibles e inembargables" (Art. 63).

- “... tendrán derecho a una formación que respete y desarrolle su identidad cultural..."(Art. 68).

- Circunscripción especial para asegurar la participación de los grupos étnicos en el Senado y en la Cámara de Representantes (Arts. 171 y 176).

- Las autoridades de los pueblos indígenas podrán ejercer funciones jurisdiccionales dentro de su ámbito territorial, de conformidad con sus normas y procedimientos, siempre que no sean contrarios a la Constitución y a las leyes (Art. 246).

- "Son entidades territoriales los departamentos, los distritos, los municipios y los territorios indígenas" (Art. 286).

- La conformación de las entidades territoriales indígenas se hará con sujeción a lo dispuesto en la ley orgánica de ordenamiento territorial [...] los resguardos son de propiedad colectiva y no enajenable"(Art.329).

- “... los territorios indígenas estarán gobernados por consejos conformados y reglamentados según los usos y costumbres de sus comunidades y ejercen entre otras funciones la de velar por la preservación de los recursos naturales..."(Art. 330).

Según la página web de la Universidad del Rosario (s.f.), posteriormente, la Ley 60 de 1993 dictaminó que los resguardos 
indígenas habían de beneficiarse de los recursos presupuestales del país, mediante transferencias proporcionales a su número poblacional. De otra parte, con el Decreto 1088 de 1993 se reguló la creación de las asociaciones y cabildos indígenas.

La Ley 152 de 1994, por su parte, estableció la acción administrativa y coordinada de los departamentos, entes territoriales, regiones administrativas y de planeación, así como un sistema de información para elaborar diagnósticos y realizar labores de seguimiento, evaluación y control de los planes de desarrollo por parte de las entidades territoriales y de planeación. El Decreto 2164 de 1995 reglamentó parcialmente el capítulo Xiv de la Ley 160 de 1994 en lo relacionado con la dotación y titulación de tierras a las comunidades indígenas para la constitución, reestructuración, ampliación y saneamiento de los resguardos indígenas en el territorio nacional. En 1996 se expidió el Decreto 1397, por el cual se creó la Mesa Permanente de Concertación con los pueblos y organizaciones indígenas y se dictaron otras disposiciones.

En el 2009, la Corte Constitucional colombiana dictó el auto 004, para la protección de los derechos fundamentales de las personas y los pueblos indígenas desplazados por el conflicto armado o en riesgo de desplazamiento forzado, y un año después el 382 del 2010, que declaró que existían 35 pueblos indígenas en riesgo de extinción física y cultural.

En el año 2011 se promulgó la Ley 1448, de Víctimas y Restitución de Tierras, una iniciativa gubernamental para la prosperidad en materia de seguridad, empleo, superación de la pobreza y especialmente a fin de dictar las medidas para el restablecimiento de la confianza y un camino hacia la reconciliación mediante la reparación integral. De igual forma, dictó la política pública que creó el snariv (Sistema Nacional de Atención y Reparación Integral a Víctimas), el Centro de Memoria Histórica y 
el Departamento Administrativo de Inclusión Social y Reconciliación. Se estableció asimismo la noción de víctima (soportada a su vez por la Sentencia C-052 de 2012) individual y colectiva; se dictaron las medidas de reparación (restitución, indemnización, rehabilitación, satisfacción y garantías de no repetición) para cada tipo de víctima en sus diferentes dimensiones (individual, colectiva, material, moral y simbólica).

Los principios esenciales que orientan esta ley son, básicamente, los de: dignidad, buena fe, igualdad, justicia transicional, debido proceso, enfoque diferencial, progresividad, gradualidad, derecho a la verdad, justicia, reparación integral, colaboración armónica de las instituciones públicas y prevalencia de los tratados internacionales en materia de derechos de las víctimas.

Esta ley es secundada y pormenorizada por el DecretoLey 4633 del 9 de diciembre del 2011, "por medio del cual se dictan medidas de asistencia, atención, reparación integral y de restitución de derechos territoriales a las víctimas pertenecientes a los Pueblos y Comunidades indígenas", que a su vez, en sus primeros artículos establece el respeto al plan de vida oral o escrito, el ordenamiento ancestral, la cosmovisión y/o ley de origen, la ley natural, el derecho mayor o derecho propio, el derecho al acceso y protección del territorio, el reconocimiento y la visibilización de los daños y violaciones históricas, entre otros.

La norma en mención ha sido asimismo reglamentada por los decretos 4800, 4155, 4633 y 4635 del año 2001, que puntualizan campos específicos de la política establecida para la atención y la reparación de las víctimas de la violencia y el conflicto armado. De igual forma, el documento Conpes 3726 del 2012 fijó los lineamientos, el plan de ejecución de 
metas, el presupuesto y el mecanismo de seguimiento del Plan Nacional de Víctimas.

\section{Marco disciplinar}

\section{Narrativas}

La investigación acerca de narrativas del pueblo nasa sobre subjetividad y autorreconocimiento como persona-indígena, en el marco de la violencia sociopolítica colombiana y la reparación integral, se pretende realizar desde la perspectiva epistemológica del socio-construccionismo y una tradición teórica que acoge postulados de una psicología cultural centrada en la psicología popular de Bruner, la cual adopta lo narrativo como principio organizativo, pues comprendemos el mundo narrándonos la trama construida. Es necesario dilucidar que este eje categorial de narrativas ha sido ampliamente estudiado por autores como Theodore Sarbin, Britton y Pellegrini, Hyden White, Keneth Gergen y Jerome Bruner.

En este trabajo se tienen en cuenta las propuestas de Bruner y Gergen, quienes a pesar de converger desde perspectivas epistemológicos diferentes, concluyen que las exposiciones narrativas están incrustadas en la acción social, mostrando una gran sensibilidad en la base sociocultural y sus sistemas de significación, de manera que las narraciones del yo no son posesiones exclusivas del individuo, sino de las relaciones, pues son productos del intercambio social. Como retoma Bruner (1990) de Clyde Kluckhohn, los seres humanos no terminan en su propia piel, son expresión de la cultura.Además, “[...] la narración es un mecanismo fundamental de comprensión de sí mismos y de los otros, por lo que la relación entre la narrativa y la formación o transformación es una reflexión sobre la identidad" (Larrosa, 1998, p. 388). 
Para el estadounidense Gergen (2007), las narrativas hacen que los acontecimientos sean socialmente visibles y establezcan característicamente expectativas para acontecimientos futuros, es decir, se vuelven expresión política, en tanto también delimitan y provienen de la interacción con el otro. Por tal motivo, se adopta esta visión para examinar las narraciones (autonarraciones) como formas sociales de dar cuenta que funcionan como historias orales, que cumplen la función de autoidentificación, autojustificación, autocrítica y solidificación social, en el marco de la reparación integral. En esta línea, "la vida es un acontecimiento narrativo" (Gergen, 2007, p. 69), y a su vez la narración es un dispositivo para lograr que los acontecimientos sean inteligibles, para darle organización y sentido al mundo, pues como sostiene White, en muchos sentidos la palabra es el mundo.

Finalmente, al utilizar la categoría de narrativas, se hace indispensable revisar los criterios de una narración inteligible de Gergen y los rasgos de la narrativa de Bruner, entendiendo que - como afirma Sarbin - si la psicología es historia y se acepta que la historia es narración, se puede decir, con la brevedad y contundencia de una fórmula, que la psicología social es narración. El proponernos el uso de este eje conceptual supone al mismo tiempo retos metodológicos, epistemológicos y pragmáticos como investigadores, en tanto se han de reconocer las emociones como integrantes esenciales del metarrelato, condicionantes del parámetro de significación para los contenidos de la memoria y propias del estilo comunicativo de los actores indígenas. Además, movilizan sus creencias.

Para poder visibilizar los relatos es necesario ponerse en sintonía con su cuadro cosmogónico, para validar, legitimar y escuchar activamente, desde el entendimiento de otra manera particular de connotar la realidad, teniendo en cuenta 
un marco de referencia salido del esquema de la colonización del pensamiento occidental. Esto supone, además, poner en contexto las versiones que abren el espacio de la memoria incluyente y la visibilización de comunidades invisibilizadas, para finalmente convocar a los investigadores a la construcción de conocimiento desde el reconocimiento de las relaciones de poder, de la otredad como lugar válido para existir y narrar, que suponen el trabajo del psicólogo en un país marcado por una realidad sociopolítica impregnada de violencia.

La narración tiene la función de dotar de sentido al mundo, pues procede de sistemas de referencia estructurados, es decir, marcos interpretativos otorgados cultural y socialmente, en tanto que la narrativa como marco social de la memoria se consolida debido a que esta última conserva aquello que le es significativo, y esta significación obedece a una historia entretejida con la cultura y la historia de vida. Como señala Bruner (citado en Mendoza, 2004), "la experiencia y la memoria del mundo social están fuertemente estructuradas no sólo por concepciones profundamente internalizadas y narrativizadas de la psicología popular sino también por las instituciones históricamente enraizadas que una cultura elabora para apoyarlas e inculcarlas". De manera que lo que no se estructura de forma narrativa, se pierde en la memoria.

De igual forma, estos modelos narrativos se sustentan en la hermenéutica, pues de acuerdo con Bruner (citado en Mendoza, 2004), se intenta establecer una lectura del texto completo y para ello apelamos a lecturas de sus expresiones parciales, intentando dotar al todo de sentido.

Comunidades como las indígenas utilizan la oralidad como recurso narrativo para salvaguardar su historia, cosmogonías e identidad, contrarrestando el riesgo del olvido. Por esta razón, sus narrativas tienen tendencia a la repetición y se 
acoplan a un producto social de colonización y vulneración. Es por ello que autores como Eco (citado en Mendoza, 2004) sostienen que la "memoria colectiva se las arregla, a veces, para sobrevivir a las censuras del poder y a los silencios de la historia”.

Para Bruner (citado en Rojas, 2013), dentro de las dos modalidades de pensamiento, la pragmática y la narrativa, se producen argumentos y relatos respectivamente. En estos últimos, el eje central es la similitud en la vida, pues tienen la posibilidad de significar la experiencia. A su vez, el lenguaje es vehículo productor de significados y producido por relaciones. Según Bruner, el estudio apropiado del hombre está basado en la conexión indispensable con el mundo cultural, en tanto se hace necesario socavar las narraciones del mundo de la cultura para contribuir a la construcción del conocimiento.

Para el psicólogo social, el lenguaje y la cultura se asumen como interdependientes, como tejedores mancomunados en la construcción de herramientas que permiten la vida en comunidad, a través de la construcción de sistemas simbólicos que dan cuenta de "procesos de construcción y utilización de significados que conectan al hombre con la cultura [...] procesos de interpretación y negociación de significados compartidos" (Bruner, 1990, p. 28).

Con el paso del tiempo son tres las cuestiones que posibilitan la narrativa: a) la eficacia a distancia: hablar de objetos sin tenerlos físicamente; b) la arbitrariedad: los signos pueden no parecerse a lo referido; y c) la gramática de casos: cierta sintaxis. Así,"el sacerdote-actor ritual puede formular con sus palabras un buen augurio para la siembra, así como el cronista que relata un combate con las tribus vecinas o el padre que habla a su hijo de ancestros a imitar; y todo esto puede ser dicho, años más tarde, en cualquier sitio, junto al hogar, a una 
sola persona o a muchas, o inclusive a uno mismo" (Bruner, citado por Mendoza, 2004).

De acuerdo con Gergen (2007), los criterios que explicitamos a continuación parecen ser primordiales en la construcción de una narración inteligible para segmentos importantes de la cultura contemporánea. En primer lugar, el establecer un punto final apreciado, pues un relato aceptable tienen que delimitar una meta, un acontecimiento que explicar, un estado que alcanzar o evitar, un resultado de significación o, dicho más informalmente, un "punto". En segunda instancia, seleccionar los acontecimientos relevantes para el punto final, en tanto los tipos de acontecimientos que pueden aparecer en la exposición, reduciendo grandemente la mirada de candidatos a la "cualidad de acontecimiento". Un relato inteligible es aquel en el que los acontecimientos sirven para hacer que la meta sea más o menos probable, accesible, importante o vivida (Gergen, 2007).

De igual manera, se tienen en cuenta la ordenación de los acontecimientos y la estabilidad de la identidad, ya que la narración bien formada es característicamente aquella en la que los personajes (o los objetos) del relato poseen una identidad continua o coherente a través del tiempo. Por otra parte, las vinculaciones causales y signos de demarcación, teniendo en cuenta que la mayoría de relatos apropiadamente formados emplean señales para indicar el principio y el final.

Para Gergen (2007), las narrativas se distinguen entre las progresivas y las regresivas. Las primeras vinculan entre sí acontecimientos, de tal modo que el movimiento a lo largo de la dimensión evaluativa a través del tiempo sea incremental, en tanto que en las segundas el movimiento es decreciente. Al mismo tiempo, el autor considera que en la cultura contemporánea algunas formas de narrativas son la narración trágica 
y la comedia-novela. Describir las formas de narración, junto al drama que se desenvuelve a través de ellas, supone trabajar en la exposición de yoes potenciales, en tanto el narrador debe mantener la inteligibilidad — ser reconocible con un pasado y un futuro- en la cultura, por lo que utiliza las reglas aceptadas en ella para la construcción narrativa.

Bruner (1990) distingue algunos rasgos del pensamiento narrativo y de la narración, los cuales se intrincan por medio del lenguaje y se dificulta su distinción. En primera instancia, los eventos ocurren en un marco temporal, por lo que son diacrónicos; por otra parte, retoma acontecimientos particulares, pero su destino va más allá, por lo que la narrativa es particular. De igual forma, tienen una composición hermenéutica, tanto en su comprensión como en su composición, ya que dependen de la capacidad humana para procesar e interpretar, y se debe prestar atención a los dominios contextuales, las intenciones, las atribuciones y el conocimiento presupuesto, la canonicidad y la ruptura con la legitimidad, pues la narrativa no consiste tanto en fabular nuevos relatos, como en convertir lo que anteriormente era familiar en incierto o problemático, hacer extraño lo ordinario.

En este sentido, la referencialidad contempla que la narrativa no es dependiente de una correspondencia estricta con la realidad, por cuanto la verdad narrativa es juzgada por su verosimilitud y no por su verificabilidad. El género, a su vez, implica maneras de comprender las narrativas y proveer guías interpretativas al público, y también existe la necesidad de tener legitimidad cultural, por lo que se evidencia normatividad. Finalmente, es preciso mencionar la sensibilidad contextual y la negociabilidad, junto con la acumulación narrativa, ya que, en primer lugar, la narrativa se analiza por medio de los presupuestos propios y bajo la luz de las presuposiciones del 
narrador. En definitiva, el producto de una cultura es la acumulación de historias del pasado que posibilitan la continuidad en el presente (Morales, 2005).

\section{Conclusiones}

Dentro de la primera fase epistemológica y conceptual del proyecto Construcciones narrativas sobre construcciones de subjetividad y autorreconocimiento indigena del pueblo nasa. Un pueblo de ancestros, luchas y reivindicaciones, es posible mencionar las siguientes conclusiones:

a) No existe un consenso entre las diferentes instituciones nacionales (ministerios/departamentos) con respecto al número total de pueblos, comunidades y personas que honran la diversidad étnica del país, aumentando así el desconocimiento de la sociedad mayoritaria y de los mismos pueblos indígenas sobre su tasa poblacional y por ende sobre otro tipo de características socioculturales, históricas y económicas.

b) Reconocimiento de la intrincada lucha por la reivindicación de derechos del pueblo nasa-paez como un legítimo otro, que difiere en cosmovisión y prácticas, puntualizando en sus concepciones, temporalidad, armonía y territorio ancestral.

c) El pueblo nasa lleva a cabo una búsqueda profunda por autodefinirse y resignificar nociones dentro de su propia comunidad, mediante la creación de figuras como kiwe thëgu o guardia indígena, y de igual forma, buscando el reconocimiento de la sociedad mayoritaria sobre su existencia y su legitimidad.

d) El llamado pueblo de luchas, reivindicaciones y resistencias ha generado dispositivos para ir en contravía 
de la trasgresión cultural que ha sufrido, en materia de la formalización sobre la propiedad de sus tierras, el goce de territorio-ambiente sano y ecológico, las pérdidas de sus congéneres, la sensación de inseguridad y violación de la libre movilización por el territorio.

e) El segundo pueblo indígena más grande de Colombia requiere que en los escenarios de diálogo/acercamientos actores, como los de participación política (consulta previa) sean visibles sus necesidades particulares.

f) Las narrativas esbozan las particularidades de indigenismo de la nación nasa, aportan a los procesos propios de la comunidad por autodefinirse, al empoderamiento político y a resignificar las maneras de acercarnos a dicho pueblo como cultura occidental.

g) El autorreconocimiento comprende la construcción de subjetividad y el entretejido de intersubjetividades, los procesos de empoderamiento en lucha y el mecanismo de resistencia de los pueblos, pues somos sujetos en proceso.

h) Las narraciones son expresiones políticas en sí mismas, porque delimitan y provienen de la interacción con el otro, funcionan como historias orales que cumplen la función de autoidentificación, autojustificación, autocrítica y solidificación social. Comunidades como las indígenas utilizan la oralidad como recurso narrativo para salvaguardar su historia, cosmogonías e identidad, contrarrestando el riesgo del olvido, y por esta razón sus narrativas tienden a la repetición y se acoplan a un producto social de colonización y vulneración.

i) Develar la subjetividad nasa a través de las narrativas pone en evidencia metarrelatos sobre aproximaciones 
a la reparación integral de este pueblo, contribuyendo desde la disciplina psicológica a la permanencia física y cultural de los pueblos y comunidades indígenas, a través de la divulgación de resultados y la invitación de disciplinas afines a la discusión de estos.

\section{Referencias}

Asamblea Nacional Constituyente (1991). Constitución Política de Colombia. Bogotá D.C.: Presidencia de la Republica de Colombia.

Bravo, O. (2011). Trauma, memoria, justicia y reparación. Revista Electrónica de Psicología Social Poiésis, (22).

Bruner,J. (1990). Actos de significado. Más allá de la revolución cognitiva. Madrid: Alianza Editorial.

Congreso de la República de Colombia (1890). Ley 89 de 1890 (noviembre 16) Por la cual se determina la manera como deben ser gobernados los salvajes que se reduzcan a la vida civilizada. Bogotá, D.C.: Presidencia de Colombia.

Congreso de la República de Colombia (1991). Ley 21 de 1991 (marzo 4) por medio de la cual se aprueba el convenio número 169 sobre pueblos indígenas y tribales en países independientes, adoptado por la $76^{\text {a. }}$ reunión de la Conferencia General de la oiт, Ginebra 1989. Bogotá,D.C.: Presidencia de Colombia.

Congreso de la República de Colombia (1995). Decreto 2164 de 1995 (diciembre 7) Por el cual se reglamenta parcialmente el Capítulo xiv de la Ley 160 de 1994 en lo relacionado con la dotación y titulación de tierras a las comunidades indígenas para la constitución, reestructuración, ampliación y saneamiento de los Resguardos Indígenas en el territorio nacional. Bogotá: D. C.: Presidencia de Colombia. 
Congreso de la República de Colombia (1995). Ley 160 de 1994 (agosto 3) Por la cual se crea el Sistema Nacional de Reforma Agraria y Desarrollo Rural Campesino, se establece un subsidio para la adquisición de tierras, se reforma el Instituto Colombiano de la Reforma Agraria y se dictan otras disposiciones. Bogotá, D.C.: Presidencia de Colombia.

Congreso de la República de Colombia (2011). Ley 1448 de Victimas y restitución de tierras. Bogotá, D.C. Diario oficial 48096 de junio 10 de 2011. Presidencia de Colombia.

Corte Constitucional de la República de Colombia (2009). Auto 004. Protección de derechos fundamentales de personas e indígenas desplazados por el conflicto armado en el marco de superación del estado de cosas inconstitucional. Bogotá, D. C.: Presidencia de Colombia.

Corte Constitucional de la República de Colombia (2010). Auto 382. Seguimiento sentencia T-025/04 y auto A004/09. Bogotá, D. C.: Presidencia de Colombia.

Corte Constitucional de la República de Colombia (2011). Decreto-ley 4633 (diciembre 9) Por medio del cual se dictan medidas de asistencia, atención, reparación integral y de restitución de derechos territoriales a las víctimas pertenecientes a los pueblos y comunidades indígenas. Bogotá, D. C.: Presidencia de Colombia.

Díaz Gómez, A. y González Rey, F. (2005). Subjetividad: una perspectiva histórico-cultural: Conversación con el psicólogo cubano Fernando González Rey. Universitas Psychologica, 4 (3), 373-383. Recuperado el $1^{\circ}$ de diciembre del 2014, de http:// www.scielo.org.co/scielo.php?script=sci_arttext\&pid=S165792672005000300011\&lng=en\&tlng=es

Equipo Nacional de Salvaguardia (s.f.) Plan de salvaguardia de la nación Nasa. Ministerio del Interior. Recuperado de http:// 
www.mininterior.gov.co/sites/default/files/p.s_nasa_version_preliminar.pdf

Gergen, K. (2007) Construccionismo social. Bogotá: Universidad de los Andes-ceso. Recuperado de http://www.taosinstitute. net/Websites/taos/images/PublicationsFreeBooks/Gergen_construccionismo_social.pdf

Guilis, G. (2005). El concepto de reparación simbólica. Memorias Seminario Internacional de Integración de Abordajes y Acciones Psicosociales en la Asistencia Jurídica a Víctimas. Bogotá: Corporación Avre. Recuperado de http://www. corporacionavre.org/files/pdf/SeminarioInternacional/capitulo1.pdf

Mendoza, J. (2004). Las formas del recuerdo. La memoria narrativa. Athenea Digital, (6), 1-16. Recuperado de http://ddd. uab.es/pub/athdig/15788946n6a11.pdf

Morales, J. (2005). Teoría narrativa de la psicología social en el modo de ser literario. Tesina de la Universidad Autónoma de Barcelona. Recuperado de http://www.tdx.cat/bitstream/ handle/10803/5442/jmg1de1.pdf?sequence=1

Observatorio del Programa Presidencial de Derechos Humanos y Derecho Internacional Humanitario (2010). Diagnóstico de la situación del pueblo indígena nasa o paez. Recuperado de: http://www.derechoshumanos.gov.co/Observatorio/Documents/2010/DiagnosticoIndigenas/Diagnostico_NASAP\%C3\%81EZ.pdf

Página Oficial Observatorio por la Autonomía y los Derechos de los Pueblos Indígenas en Colombia (ADPI) (s.f.). Pueblo nasa. Recuperado de http://observatorioadpi.org/nasa

Página oficial onic (s.f.). Pueblos indígenas. ¿̇Cuáles son, cuantos y donde se ubican los pueblos indígenas de Colombia? Recuperado de http://cms.onic.org.co/pueblos-indigenas/ 
Página oficial Universidad del Rosario (s.f.) Legislación colombiana para comunidades étnicas. Recuperado de http://www. urosario.edu.co/jurisprudencia/catedra-viva-intercultural/ ur/Legislacion-colombiana-para-comunidades-etnicas/ y http://190.25.231.237:81/gruposEtnicos/doc/NormatividadResguardosIndigenas.pdf

Rojas, L. (2013). Narrativa historica, narrativas cotidianas: la memoria como campo de lucha en el caso de la masacre de Trujillo (tesis). Fundación Universitaria Los Libertadores, Bogotá. 



\section{Derecho humano al agua en la comunidad wayúu bajo la figura matrilineal*}

Melanie Vangrieken Alvarado**
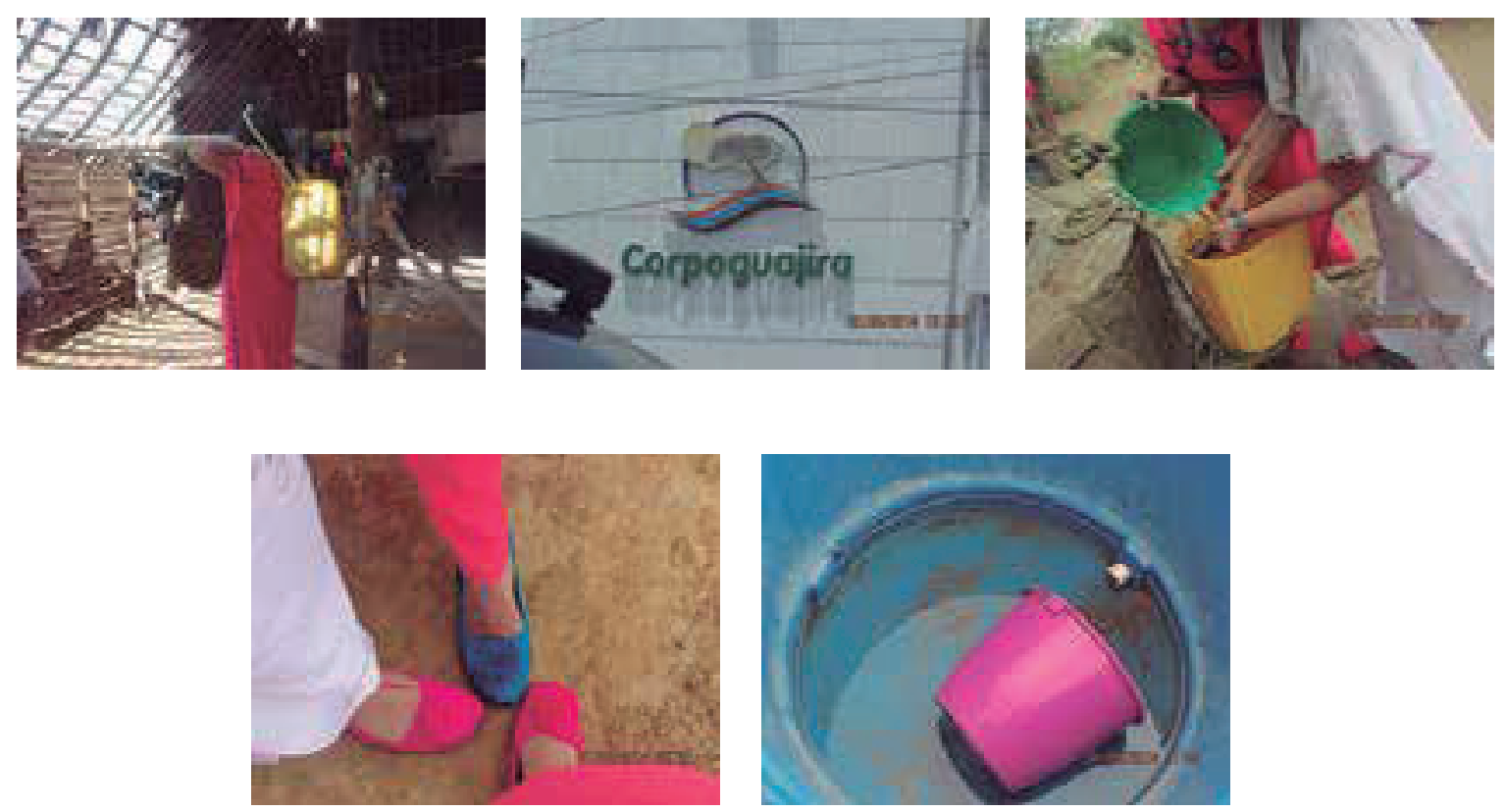

* Agradecimientos especiales a mi tutora Judith Echeverría Molina y a mis compañeras Carla Castellanos Gómez, Nataly De las Salas Castro y María Daniela Guzmán Gordon.

** Estudiante en formación en investigación, Universidad del Norte, División de Derecho, Ciencia Política y Relaciones Internacionales, Departamento de Derecho, V semestre, 2015. Correo electrónico: melanievangrieken@gmail.com. 


\section{Resumen}

A principios de mayo del 2014, en el afán de comprender un poco más de la cultura wayúu para poder llevar a cabo un nuevo proyecto de investigación que surgió en la Universidad del Norte, la literatura etnográfica - leída por primera vez en la obra de un poeta wayúu autor de "En las hondonadas maternas de la piel", Vito Apüshana, y otros autores como Estercilia Simanca y Miguel Angel Jusayu— ayudó a recrear el mundo indígena y conocer el concepto de agua desde su cosmovisión, y dio origen a esta investigación.

Lo más interesante es cómo el pueblo wayúu expresa a través de esta literatura la cotidianidad de la vida, pero acompañada de un elemento sagrado, y cómo a través de la observación cultiva la palabra, con una estética maravillosa donde el agua - o wuin en wayuunaiki- es un elemento fundamental de inspiración. Por un lado, está el mar Caribe, hacia el norte, y por el otro, el río Ranchería, uno de los escenarios más comunes en los escritos wayúus.

Otro aspecto fascinante de esta cultura consiste en un equilibrio armónico, donde el ser humano es apenas una parte, y no es el amo de la tierra. Se refiere a pensar que también hay un algo en las plantas, en los ríos, en toda la naturaleza que los convierte en deidades, como lo es juya, y resulta que según la creencia de los wayúus el río no es solo el agua que fluye, sino que además constituye un elemento sagrado que sostiene y conecta toda la vida, y de aquí nace un profundo respeto por ella.

Con el estudio sobre el pueblo wayúu, asentado en los terrenos ancestrales de la península de la Guajira al norte de Colombia, este escrito tiene como propósito presentar un análisis sobre el efecto que tiene el reconocimiento del derecho al agua como derecho humano en las condiciones de vida y la 
realización de los demás derechos humanos de las mujeres y niñas wayúus, como también en la noción jurídica fundamental del Estado para garantizar el acceso a sistemas de agua potable y al saneamiento de esta comunidad indígena.

Se parte de la recopilación de los pronunciamientos en materia del derecho humano al agua, el estudio de la importancia del tema en cuestión y un análisis de este derecho humano desde una perspectiva de género. Continuamos con la descripción de las condiciones de los sistemas de abastecimiento de agua en las comunidades wayúus y la identificación de las políticas públicas que existen en el departamento de la Guajira para garantizar el derecho humano al agua en estas comunidades, y posteriormente reconocemos las tradiciones, la cultura, el vocabulario, los conceptos y las necesidades de los asentamientos wayúus, por medio de la construcción del concepto de agua según las wayúus, además de la descripción del rol de las mujeres y niñas con respecto al abastecimiento de agua y sus acciones para hacer valer este derecho, con el fin de explicar cómo se les garantiza el derecho humano al agua a las mujeres y niñas wayúus.

\section{Introducción}

Desiertos llenos de encanto y embrujo, playas de carbón bordadas en blancas salinas y aguas cristalinas forman parte del paraíso guajiro, tierras exóticas orgullo de los paisajes colombianos; sin embargo, según la Organización de las Naciones Unidas (oNU), las condiciones de vida en el desierto se han visto deterioradas en los últimos años en el norte de Colombia. Las mujeres indígenas wayúus luchan para garantizar la supervivencia de su comunidad, a pesar de los cada vez más escasos recursos de agua.

En la Guajira, de acuerdo con el Plan de Manejo Ambiental de la Gobernación, las condiciones ambientales, caracterizadas 
por bajas precipitaciones anuales (por debajo de $500 \mathrm{~mm} / \mathrm{año}$ ), altos valores de evapotranspiración (generalmente superiores a $1500 \mathrm{~mm} / \mathrm{año}$ ) y bajas condiciones de humedad, generan escasez de agua, lo que se convierte en una de las mayores problemáticas para las comunidades indígenas wayúus, al ser el 20,5\% de la población indígena nacional (Departamento Nacional de Planeación [DNP], Instituto Colombiano de la Reforma Agraria [Incora], 1997) y el 48\% de la población de la Guajira, según el Censo General 2005, con una tasa de cobertura de acueductos de tan solo el 52\%.

Ante dicha situación, esta investigación promueve la idea del agua potable y el saneamiento como indispensables para la vida y la salud, y fundamentales para la dignidad de las comunidades wayúus, en especial para las mujeres y las niñas. Este apoyo se fundamenta en el reconocimiento del derecho humano al agua y al saneamiento de la Asamblea General de las Naciones Unidas, donde se sostiene que un agua potable limpia y el saneamiento son esenciales para la realización de todos los derechos humanos. Teniendo en cuenta ello, se exhorta al Estado y a las organizaciones internacionales a proporcionar recursos financieros, propiciar la capacitación y la transferencia de tecnología para ayudar a las comunidades indígenas wayúus, y proporcionar un suministro de agua potable y saneamiento saludable, limpio, accesible y asequible para todos.

Con los grandes avances en el reconocimiento del derecho al agua como derecho humano, este proyecto aborda las desigualdades que afectan a las mujeres y a las niñas en relación con los servicios de agua y saneamiento. Además, insta a resaltar la misión del Fondo de las Naciones Unidas para la Infancia (Unicef, por su acrónimo en inglés) y promover la igualdad de derechos de las mujeres y las niñas wayúus, 
quienes soportan la carga de ir por agua, como consecuencia de lo cual pierden oportunidades para la educación, para realizar actividades productivas y para el esparcimiento. Así, se apoya su participación plena en el desarrollo político, social y económico de sus comunidades.

Sin lugar a dudas, la concientización nacional sobre el esfuerzo que las mujeres y niñas de la comunidad wayúu hacen al realizar ciertas actividades para conseguir agua en pro de su comunidad, así como las condiciones en las que se encuentran los sistemas de abastecimiento de agua en los asentamientos wayúus, serán el incentivo perfecto para los proyectos sociales, participativos y sostenibles, encaminados a promover soluciones de abastecimiento de agua, saneamiento e higiene y gestión integral de fuentes hídricas:

El problema del agua va más allá de la cuestión del acceso. En muchos países, las niñas se ven obligadas a abandonar la escuela debido a la falta de instalaciones sanitarias, y las mujeres sufren violaciones y ataques cuando van por agua. (Ban Ki-moon, Secretario General de Naciones Unidas)

\section{Metodología}

Con el fin de determinar cómo se les garantiza el derecho humano al agua a las mujeres y niñas wayúus, se empleará la metodología cualitativa orientada a conclusiones, porque se está frente a una investigación que busca interpretar y comprender la realidad social circundante de la comunidad wayúu. Además, se busca estudiar la realidad en su contexto natural, tal como sucede, intentando obtener un sentido de, o interpretar, los fenómenos de acuerdo con los significados que tienen para las personas implicadas. Esta investigación 
cualitativa implica la utilización y recolección de una gran variedad de materiales que describen la rutina, las situaciones problemáticas y sus significados en la vida de las mujeres y niñas wayúus (Rodríguez et al., 1996).

Según la orientación del trabajo, se realizará un estudio de tipo descriptivo, con la finalidad de llegar a conocer las situaciones, costumbres y actitudes predominantes, a través de la descripción exacta de las actividades, objetos, procesos y personas dentro de la cultura wayúu, sin limitarse a la recolección de datos, sino abordando además la predicción e identificación de las relaciones que existen entre dos o más variables, incluyendo las implicaciones sociojurídicas del derecho humano al agua con esta cultura (Ávila, 2006).

Las técnicas empleadas para el logro de las metas definidas en los objetivos específicos de la investigación, están constituidas por la actividad participativa y la observación etnográfica en una ranchería ubicada en el centro-este del departamento de la Guajira, en el municipio de Maicao, con una población aproximada de veinticinco mujeres y niñas wayúus. Asimismo, la revisión de documentos oficiales como el Plan de Desarrollo Departamental 2012-2015 de la gobernación de la Guajira y entrevistas a funcionarios de entes relacionados con el tema, como lo es el subdirector de Corpoguajira. Además, entre las técnicas de investigación se incluyen las entrevistas semiestructuradas, la fotografía y el video, el grupo focal — como una técnica cualitativa para el estudio de las opiniones o actitudes de un grupo- y, por supuesto, la observación científica para describir los escenarios del estudio.

\section{Resultados}

Para abarcar el tema del derecho humano al agua en la comunidad wayúu bajo la figura matrilineal, es importante resaltar 
de dónde proviene el interés de esta investigación, así como los antecedentes de esta temática.

\section{Pronunciamientos sobre el derecho humano al agua}

E1 28 de julio de 2010, a través de la Resolución 64/292, la Asamblea General de las Naciones Unidas:

[...] reconoció explícitamente el derecho humano al agua y al saneamiento, reafirmando que un agua potable limpia y el saneamiento son esenciales para la realización de todos los derechos humanos. La Resolución exhorta a los Estados y organizaciones internacionales a proporcionar recursos financieros, a propiciar la capacitación y la transferencia de tecnología para ayudar a los países, en particular a los países en vías de desarrollo, a proporcionar un suministro de agua potable y saneamiento saludable, limpio, accesible y asequible para todos. (Departamento de Asuntos Económicos y Sociales de las Naciones Unidas, 2010)

En este mismo sentido, en noviembre del año 2002, el Comité de Derechos Económicos, Sociales y Culturales adoptó la Observación General no 15 sobre el derecho al agua, cuyo artículo 1.1 establece que "El derecho humano al agua es indispensable para una vida humana digna”. La Observación no 15 también define el derecho al agua como "el derecho de cada uno a disponer de agua suficiente, saludable, aceptable, físicamente accesible y asequible para su uso personal y doméstico". En el Congreso del año 2009, los sindicatos europeos de servicios públicos iniciaron la recaudación de firmas a favor del agua como un derecho humano. "El establecimiento de normas de Iniciativa Ciudadana Europea por parte de la Comisión Europea se dio en marzo del 2011" (Comisión Europea, 2014). 
Asimismo, la Corte Constitucional colombiana también se ha pronunciado con respecto a este tema, hecho evidenciado en las diferentes sentencias proferidas por este órgano. En primer lugar, cabe resaltar que desde el inicio de su jurisprudencia, ha considerado que "el derecho de toda persona al agua es un derecho fundamental, que es objeto de protección mediante acción de tutela en muchas de sus dimensiones"(Sentencia T-418 del 2010). De igual manera, la Sentencia T-740 del 2011 establece que el agua se instituye como una necesidad básica, al ser un elemento sólido para permitir la existencia del ser humano. En el ordenamiento jurídico colombiano, el agua posee un doble vínculo, ya que se erige como un derecho fundamental y como un servicio público. En este sentido, todas las personas tienen el derecho de acceder al servicio de acueducto en condiciones de calidad y cantidad suficiente, y por lo tanto el Estado está encargado de organizar, dirigir, garantizar y reglamentar su prestación.

La Sentencia T-312 del 2012 establece que la Corte ha definido el agua como un derecho fundamental, siempre que esté destinada al consumo de cada persona, argumentando para ello que el agua es un requisito necesario para poder efectuar otros derechos. A su vez, mediante la Sentencia T-232 de 1993 se determinó que el derecho al agua es un derecho fundamental para el hombre, por conexidad con los derechos fundamentales a la vida y la salud en cuanto al consumo humano como necesidad básica. La Sentencia T- 413 de 1995, por su parte, señaló que en cuanto el derecho al agua se refiere a la salud humana y a la salubridad pública, es un derecho fundamental. Igualmente, afirmó que es prioritario atender necesidades domésticas y garantizar agua potable para la familia. 
La doctrina también se ha pronunciado sobre este tema, con diversas opiniones:

El agua es una necesidad humana indispensable para la vida, esencial para vivir con dignidad. Sin agua no hay vida posible. Se trata de un derecho humano personalísimo, urbi et orbi, erga omnes, que debe ser acatado por cualquier sociedad y todo Estado. Resulta ser una condición esencial, previa, que condiciona la existencia y el ejercicio de cualquier otro derecho humano. (Iza y Aguilar, 2009)

La existencia de un derecho fundamental referente al agua, de acuerdo con la tendencia moderna, el derecho al agua concierne el aprovisionamiento de agua potable y al saneamiento. Este derecho implica tanto derechos como obligaciones para los ciudadanos y los poderes políticos. (Smtes, 2006)

\section{Importancia del derecho humano al agua}

El tema del derecho humano al agua es de gran interés, teniendo en cuenta que " $\mathrm{El}$ agua es vital para la supervivencia y la buena salud de todos los seres humanos. El derecho al agua implica el acceso al agua potable y a instalaciones sanitarias adecuadas" (Humaniun, 2009). Por consiguiente, el derecho al agua es fundamental e indispensable para concretar otros derechos humanos y/o fundamentales, como es el caso del derecho a la salud, y por ende el derecho a la vida, ya que estos no se pueden definir sin un acceso a sistemas de agua potable limpia y al saneamiento.

Por otra parte, el derecho al agua limpia y potable es un derecho esencial y trascendental porque el agua desempeña un papel fundamental en la vida diaria y en el entorno de 
cada ser humano. De tal manera, tiene múltiples funciones, entre ellas:

- La higiene: para la higiene personal (baños, lavado de manos, etc.) y para la higiene doméstica (loza, ropa, implementos de aseo, etc.).

- La hidratación: el agua que bebemos y que nuestro cuerpo necesita.

- El saneamiento adecuado: utilizada en ciertas instalaciones, como los baños que permiten la eliminación de orina y materia fecal.

- La conservación de la salud: nos permite hidratarnos y por tanto mantener activo nuestro organismo.

- La cocción: el agua utilizada para lavar y cocinar los alimentos.

- Cultivar la tierra: empleada para el crecimiento de las cosechas.

A su vez, el tema del derecho humano al agua es importante, considerando que el agua es "el elemento principal para el desarrollo de las personas y para todas las formas de vida" (Katmandú, 2003). Actualmente, este es un tema muy discutido ya que constituye un elemento fundamental, primordial, esencial y notable para que cada persona pueda tener una vida digna. Después de quince años de debates, la Asamblea General de Naciones Unidas aprobó la resolución que reconoce y determina al agua potable y al saneamiento como un derecho humano para el uso y goce de la vida y los demás derechos fundamentales y/o humanos. Dicha resolución fue aprobada por iniciativa de Bolivia, con votos favorables de 122 países - entre ellos Congo, Angola, Antigua y Barbuda, República Dominicana, Arabia Saudita, Bangladesh, Benín, Eritrea, 
Burundi, Congo, Cuba, Dominica, Ecuador, El Salvador, Fiji, Serbia, Georgia y Haití- y 44 votos en contra.

El derecho humano al agua no es un tema importante solo para países como los mencionados anteriormente, sino también para Colombia, dado que este derecho ha sido reconocido tácitamente en tratados e instrumentos internacionales ratificados por el país, como Convención sobre la eliminación de todas las formas de discriminación contra la mujer y la Convención de los Derechos del Niño. El derecho al agua potable y al saneamiento básico está respaldado en las disposiciones de la Constitución Política en la parte de los fines esenciales del Estado, en los derechos económicos, sociales y culturales y en los derechos colectivos y del ambiente (Defensoría del Pueblo, 2014).

\section{El derecho humano al agua desde una perspectiva de género}

La mujer y el hombre realizan diferentes actividades con respecto al abastecimiento del agua y los sistemas hidrológicos. En las culturas indígenas, las mujeres y las niñas son las encargadas del suministro, la gestión, la provisión y el abastecimiento del agua que necesitan la comunidad y la familia para la higiene, para alimentarse, para la conservación de la salud, para cultivar la tierra, entre otras actividades (Molinares y Echeverría, 2011). A causa de que las mujeres y las niñas de esta comunidad se encuentran en constante contacto con fuentes de agua no potable, están más expuestas a la contaminación, a enfermedades e incluso a abusos sexuales, ya que deben recorrer largas distancias para conseguir este recurso, entre arbustos, en el campo o sobre una montaña, lo que las pone en riesgo porque deben alejarse mucho para hacer sus necesidades y encontrar privacidad. El tiempo que las mujeres 
utilizan en la gestión, uso y provisión del agua a sus hogares implica una importante carga adicional para ellas, como también una reducción del tiempo disponible para la realización de otras actividades, como las relacionadas con la educación, la formación, la capacitación y la generación de iniciativas económicas o involucramiento en actividades remuneradas, así como su participación en actividades culturales, de recreación o de participación política con importantes implicaciones en la vida tanto privada como comunitaria (Ledo, 2005).

En relación con el tema de las mujeres y las niñas y el derecho humano al agua, en el año 2000 Tatiana Ordeñana Sierra desarrolló una investigación titulada Los derechos de las mujeres son derechos bumanos, que se ocupa de los derechos humanos y su declaración internacional, pero de igual manera abarca los derechos de las mujeres. En dicha investigación se hace un énfasis práctico en la declaración de los derechos humanos, la abolición de toda esclavitud y las libertades de los seres humanos. De igual manera, se hace referencia a la igualdad de género y, como necesidad básica para el progreso de la humanidad, que se elimine la discriminación, tal y como se declara en la proclamación de la Conferencia Internacional de Derechos humanos celebrada en Teherán en mayo de 1968, cuyo inciso 15 reza: "La discriminación de que sigue siendo aún víctima la mujer en distintas regiones del mundo debe ser eliminada" (Bernales-Ballesteros, 1996).

Hoy en día la mujer wayúu desempeña los roles más importantes dentro de su comunidad, lo que demuestra Carlos A. Pulgarín (1997) en su artículo "La mujer Wayuu", publicado en el diario El Tiempo, donde se explica que en la cultura wayúu la mujer desempeña un papel fundamental y esencial, hecho evidenciado en que cuando nace una niña,los miembros 
de la comunidad consideran que ello es una bendición de los grandes dioses.

\section{Condiciones de los sistemas de abastecimiento} de agua en las comunidades wayúus

Para las comunidades wayúus el abastecimiento de agua es uno de los principales obstáculos, debido a las desfavorables condiciones ambientales de la Guajira caracterizadas por las bajas precipitaciones, donde el agua subterránea es la única fuente permanente de abastecimiento. Por lo tanto, la carencia de corrientes hídricas y unas precipitaciones anuales por debajo de los $500 \mathrm{~mm}$ hacen que gran parte de los sistemas de abastecimiento giren en torno a la provisión de agua del subsuelo.

A lo largo del tiempo los wayúus han tenido que hacer grandes recorridos para lograr el aprovisionamiento del agua, actividad realizada principalmente por mujeres y niñas, en la cual invierten diariamente una considerable cantidad de tiempo y fuerza laboral, lo cual limita la realización de otros derechos humanos como la educación. Aun hoy el acarreo se realiza en burros - en las zonas donde todavía están disponibles-, bicicletas, carretas, vehículos, o por lo general a pie cuando las fuentes son cercanas, a menos de 250 metros (Benavídez, 2009).

La escasez de sistemas adecuados de abastecimiento de agua y saneamiento implica que para el 100\% de la población el principal sistema de suministro de agua sea el acarreo y la utilización de aguas lluvias. Se capta agua de diversas fuentes, tales como río, manantial, jagüey, albercas, agua de carrotanques que traen desde los principales municipios, agua subterránea movida por molinos y grandes reservorios. Según el contrato de consultoría no 301 de la Gobernación de la Guajira, por 
medio del cual se realizó una evaluación social y un plan de pueblos indígenas, las fuentes de abastecimiento de agua de la comunidad wayúu que han perdurado por años y forman parte de sus tradiciones ancestrales son: las casimbas, los jagüeyes, los molinos eólicos, las aguas lluvias, los carrotanques, los pozos profundos y los ojos de agua salada. En los siguientes párrafos se describen algunas de estas fuentes de abastecimiento, por su carácter inusitado.

Los jagüeyes son reservorios hechos en tierra, constituyen la principal fuente de abastecimiento de los indígenas wayúus que habitan en la zona rural de la Guajira. En la mayoría de los casos el agua que se recoge en estos sistemas de almacenamiento es consumida por las personas sin ningún tratamiento previo, lo que propicia situaciones de alto riesgo para la salud humana, particularmente en la población infantil (Revista Mundo Cerrejón, 2010, (59), 9).

Las casimbas, según el antropólogo Benson Saler, son depresiones abiertas y se ubican con frecuencia en depresiones que se llenan con agua lluvia. Constituyen una de las formas de abastecimiento de agua más comunes dentro de la comunidad wayúu.

Los pozos: son agujeros, excavaciones o túneles verticales que perforan la tierra, hasta una profundidad suficiente para alcanzar lo que se busca, en el caso de las comunidades wayúus una reserva de agua subterránea.

Las albercas: son construcciones hidráulicas, bien excavadas en tierra, bien realizadas, con fábrica de ladrillo, tapial o mampostería, en forma de estanque, para almacenar agua.

Molinos eólicos: utilizados con bombas eólicas de agua como un mecanismo de bombeo que funciona accionado por la fuerza del viento. En general, son utilizados a pequeña escala para abastecer de agua potable. 


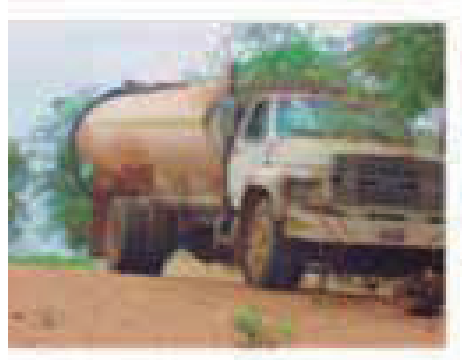

Carro

tanque

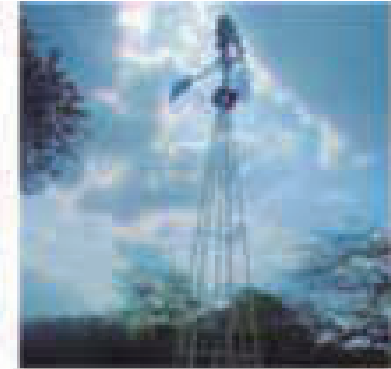

Molinos eólicos

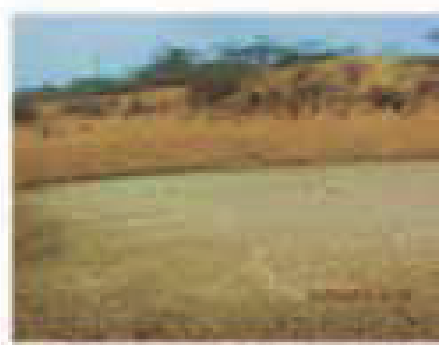

Jagüeyes

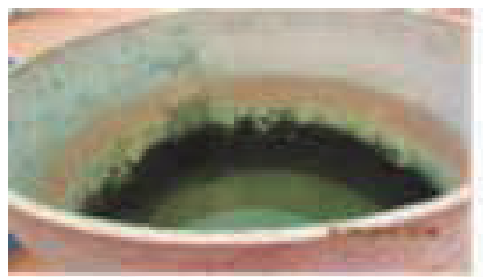

Casimbas
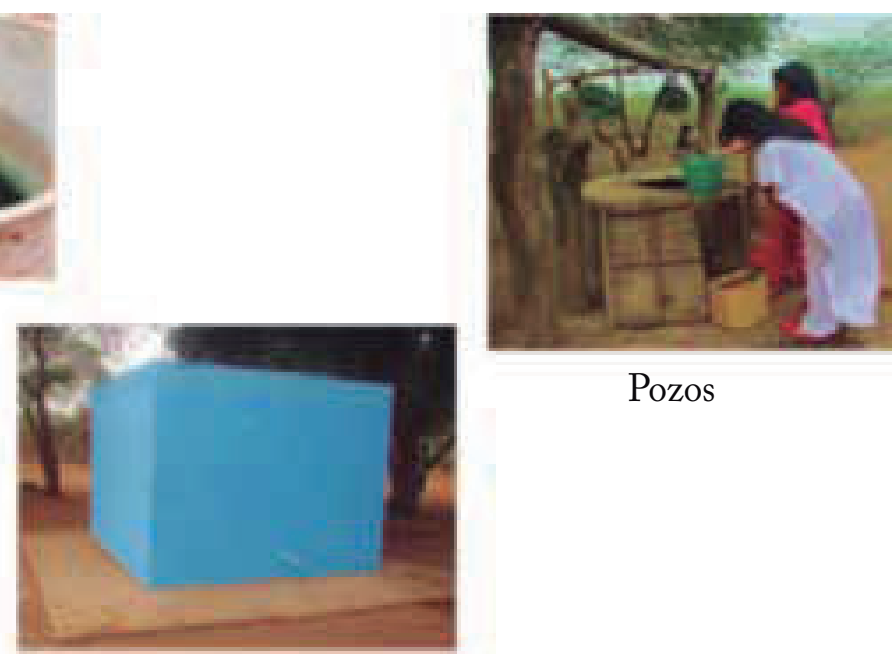

Pozos

Albercas

Figura 1. Fuentes de abastecimiento de agua de la comunidad wayúu

Fuente: Proyecto de investigación Derecho humano al agua en la comunidad wayúu bajo la figura matrilineal (2014)

\section{Planes y políticas públicas con respecto al derecho humano} al agua en el departamento de la Guajira, Colombia

Con el fin de garantizar y ejecutar el derecho humano al agua en el departamento de la Guajira, a lo largo del tiempo se han desarrollado diferentes planes para que, de conformidad con la ley y las necesidades de la población, este recurso se utilice de la mejor manera posible. A continuación algunos ejemplos. 


\section{Plan departamental para el manejo empresarial} de los servicios de agua y saneamiento (2010)

Elaborado por el Ministerio de Ambiente, Vivienda y Desarrollo Territorial, este plan se fijó el propósito de poner el tema de agua en la agenda pública nacional y local. El problema de falta de agua potable y la ausencia de saneamiento básico en miles de hogares colombianos no podía seguir siendo ignorado y tampoco podía ser abordado exclusivamente desde el campo de los servicios públicos. La situación tenía que ser abordada como lo que era: un problema de dignidad humana, habida cuenta que más de setecientos municipios pequeños y medianos, más de doce millones de colombianos, requerían una respuesta real a sus necesidades.

Con este horizonte, por cerca de ocho años, el equipo humano de la antigua Dirección de Agua Potable y Saneamiento Básico, hoy Viceministerio de Agua y Saneamiento, trabajó para elaborar, producir e implementar una política pública que transformara al sector definitivamente. A este fin se estructuró la política de Planes Departamentales de Agua Potable y Saneamiento Básico, como un grupo de estrategias presupuestales, fiscales y técnicas que, coordinadas por los departamentos, permitieran planificar adecuadamente la implementación de este recurso en pro de los servicios públicos de acueducto y alcantarillado.

A la fecha se ha podido desarrollar un proceso de diagnósticos de la situación de los municipios con relación a la prestación de los servicios de acueducto, alcantarillado y aseo. De esta manera, las inversiones programadas y la ejecución de obras físicas del Plan obedecen al análisis de las necesidades reales de la población afectada, promoviéndose así la eficiencia en la aplicación de los recursos aportados. 


\section{Diagnósticos sectoriales del departamento de la Guajira}

Se realizaron y se concertaron en su totalidad los diagnósticos de los servicios de acueducto y alcantarillado y su componente ambiental e institucional. Esta actividad, que se llevó a cabo en los años 2004 y 2005, implicó que se valoraran necesidades de inversión en todos los municipios, con base en planes maestros existentes y en la información suministrada por los entes territoriales. Teniendo en cuenta esta información, se fijaron metas de cobertura de acueducto y alcantarillado urbano que se plasmaron en el Documento Conpes 3430 del 2006, conciliando los diferentes diagnósticos realizados por la firma Equity, la gerencia estructuradora en el 2007 y los entregados por los operadores y la Gobernación en el 2008. E1 24 de septiembre de ese año se elaboró y firmó el acta de concertación del diagnóstico. En materia de acueducto, el departamento presenta una cobertura del 72\% y en alcantarillado el $46 \%$ (Gobernación de La Guajira y Operadores, citado Conpes 3430 del 2006).

\section{Evaluación Social y Plan de Pueblos Indígenas para el} proyecto Construcción y sostenibilidad de once (11) reservorios y un (1) micro acueducto, en comunidades Indígenas de la alta Guajira (Gobernación de la Guajira, 2011)

La Guajira alberga uno de los resguardos indígenas más grandes del país, el de la Alta y Media Guajira, perteneciente a la etnia wayúu, con una extensión de 1'067505 hectáreas y una población de 121469 habitantes. Comprende la totalidad de los municipios de Uribía y Manaure y parte de los municipios de Riohacha y Maicao. La Gobernación de la Guajira se propone ubicar geográficamente once proyectos de reservorios y un acueducto para mejorar la distribución y el correcto uso y repartición del recurso agua. 
Fragmento de la entrevista realizada al subdirector de gestión ambiental Samuel Santander Lanao Robles en las instalaciones de Corpoguajira

Fecha: 02/05/2014

E: entrevistador

S: subdirector

\section{E: ¿Cuáles son las funciones de Corpoguajira con respecto al tema hídrico?}

S: La Corporación Autónoma Regional de la Guajira tiene legalmente la competencia de la administración de recursos hídricos en el departamento de la Guajira. Además, la Ley 99 le da a la Corporación la competencia para la provisión de agua a las comunidades indígenas y afrodescendientes dentro de su jurisdicción.

\section{E: ¿Cuál es el papel de Corpoguajira frente al desarrollo} de las políticas públicas con base en el agua?

S: Las políticas públicas se reflejan en la normatividad colombiana en relación con el recurso hídrico, ahí existe una competencia como por parte nuestra de administrar el recurso hídrico en todo el departamento. Adicionalmente a esto, la provisión de agua a la comunidades indígenas y afrodescendientes, nosotros implementamos programas y proyectos para atender ese mandato legal, es así como históricamente la Corporación ha hecho presencia en los municipios del departamento de la Guajira, especialmente en la comunidad indígena wayúu, en las comunidades indígenas asentadas en la Sierra Nevada de Santa Marta, llevando el suministro de agua y complementando la acción, recalcando que quien tiene la competencia directa para la prestación de servicio de agua potable a las comunidades del departamento de la Guajira son 
las alcaldías municipales, a través de la Ley 142 de Servicios Públicos, pero nosotros tenemos una función complementaria por el ordenamiento legal, y eso lo estamos realizando.

\section{E: ¿Cómo ayuda la Corporación a garantizar el derecho humano al agua en las comunidades wayúus?}

S: A través de la provisión de agua, de la construcción de sistemas de abastecimiento. Hay que recalcar que debido a la dispersión de las comunidades indígenas en el territorio, es difícil llevar solución agua, pero lo hemos venido haciendo con los diferentes sistemas no convencionales; por ejemplo, la construcción de pozos profundos, de jagüeyes, llevar agua a través de los carrotanques, y de esa manera hemos logrado penetrar y cumplir con ese ordenamiento normativo.

\section{E: La Corporación a través de la relación con las comunidades wayúus, ¿cuál considera, a través} de su experiencia, que es el papel de las mujeres y las niñas en todo el proceso de abastecimiento?

S: Por cultura, podemos observar que la mujer tiene un papel preponderante en la cultura wayúu. Vemos que es quien va a buscar el agua. Por la dispersión los sistemas no pueden ser tan puntuales, ubicados en sitios donde se centraliza la población. En muchos casos las comunidades tienen que recorrer muchos kilómetros, de cinco a diez, para buscar el agua, y allí la mujer desempeña ese papel importante, debido a que es ella quien va y busca el agua para poder suministrar a sus comunidades, a su gente y su familia. Eso hay que resaltarlo en la mujer guajira, ese liderazgo y esa capacidad de servicio que tiene con su comunidad. 


\section{E: ¿Qué proyectos ha llevado a cabo la Corporación?}

La Corporación desde su existencia, que lleva ya treinta años, ha hecho presencia y ha mantenido un liderazgo en la provisión de agua a las comunidades indígenas, y son muchos los proyectos. Podríamos darle el listado, ya que no podría enumerarlos, porque se gastaría todo el tiempo para suministrar esa información, pero podemos darle un listado de todas las acciones que hemos venido realizando con la construcción de pozos profundos, jagüeyes, suministro de agua a través de carrotanques, sistemas de potabilización de agua salobre, construcción de albercas. Todo el esfuerzo que ha sido necesario hacer para provisión de agua a las comunidades, y tenemos las evidencias para demostrar que de esa manera se ha realizado.

\section{El papel de las mujeres y niñas wayúus en el abastecimiento de agua}

Se da respuesta a esta pregunta a través de un grupo focal en La Ranchería "Campamento”, con la participación de un grupo de doce mujeres (quienes reservaron su identidad) de la ranchería anteriormente mencionada (fragmento de las intervenciones: $\mathrm{M}$ : mediador P: participantes).

\section{M: ¿Cuál es el rol de las mujeres y niñas wayúus en el abastecimiento de agua?}

P: Es un derecho que se adquirió en el 2010, pero nosotros estamos en una comunidad muy pobre de agua, aquí no hay agua por ninguna parte, ni un río ni nada, entonces es muy difícil el agua, solo hay unos molinos, y ¿̇a quién le toca?... a la mujer. El trayecto es muy largo para conseguir el agua, y para las niñas, así que en esta comunidad carecemos de agua. 
M: ¿Y eso afecta que las niñas vayan a la escuela por ayudar en su casa?

P: claro, porque esta es una comunidad donde primordialmente los niños wayúus tienen que ayudar en la casa, y más la niña, ella es la que sale y busca el agua, porque eso es algo de la cultura, entonces muchas veces como no hay agua, vienen sin bañarse.

\section{M: ¿Cómo es el proceso de recolección de agua?}

P: Este proceso se hace diariamente, todas las tardes, pero por la necesidad, la recolección siempre se hace en las horas de la mañana, o en la tarde para evitar la cuestión del sol o el cansancio. El método de buscar el agua es en burro o en carreta, la distancia depende del lugar donde se vaya a buscar, dos o tres horas. Diariamente hay cuatro desplazamientos y esta actividad está a cargo de las mujeres o niñas, máximo están echando unos ochenta litros en cada viaje, porque hay un burro que le ponen los tanques, acá hay pozo, hay un jagüey, pero le falta mantenimiento y ahora mismo está totalmente seco, hay deficiencia con los tanques porque no tienen mucha limpieza y no es bueno tomar de ahí, da fiebre y enfermedades. De estas enfermedades se encargarían las madres, por su medicina tradicional, ellas mismas hacen sus recetas y esas cuestiones, a parte a ellas se les hace difícil trasladarse al hospital por la lejanía.

\section{M: ¿Cómo afecta la vulneración del derecho humano}

al agua a otros derechos humanos en las wayúus?

P: Sí son vulnerados otros derechos, porque a veces nos pasa que algunas niñas no vienen a clase porque les toca arriar agua, o sea ir en burro, hacer varios viajes todo el día y es una distancia bastante larga, se pasan todo el día arriando agua. Las mamás 
de las niñas dicen que primero es el agua, porque la utilizan para cocinar, lavar, bañarse, para todos los oficios, e igualmente algunas niñas vienen y dicen que no les dio tiempo para hacer la tarea, porque llegan del colegio y no hay agua para cocinar y les toca arriar agua toda la tarde hasta la noche, $y$ al día siguiente llegan sin hacer las tareas, y así sucede en muchas partes de aquí. Algunas personas son conscientes y les permiten a sus hijos jugar un rato, pero hay unos que no, apenas llegan tienen que arriar el agua, y es porque algunas madres piensan que el oficio de las niñas es ese, arriar el agua.

\section{Concepto de agua para las mujeres y niñas wayúus}

"Primeramente, el concepto de agua para la comunidad indígena, wayúu, es que el agua es vida; sin agua no podemos vivir y el wayúu no puede vivir sin agua, sobre todo la agricultura, para el sustento diario, para todos los quehaceres necesitamos agua, la falta de agua afecta de todas maneras, porque si en la casa no hay agua las niñas no acuden al colegio, porque no se han bañado, no tienen para cocinar los alimentos, entonces como ellos tienen que buscar el agua de un lugar tan distante, se les dificulta venir a clase, cumplir con sus labores académicas. Por ese motivo, porque es distante buscar el poquito de agua, porque ellos no tienen tampoco unas condiciones adecuadas, por lo menos una alberca, un tanque grande en el que puedan almacenar su agua y entonces es difícil, ellos únicamente traen como unas pimpinas que decimos aquí en la Guajira y es muy difícil para ellos traer esa agua que es para el sustento diario.

En la parte cultural el agua es juya, cuando en la época del invierno, juya viene a aquí a la tierra, entonces juya moja la tierra y el wayúu se alegra porque ya sus cultivos van a producir para su alimentación, entonces es muy importante porque juya 
venga juya es la lluvia a visitar la tierra porque de ahí es todo, los animales" (Mujer wayúu. Identidad reservada).

\section{Acciones de las mujeres wayúus para hacer valer el derecho humano al agua}

La mujer hace valer esos derechos, porque es ella haciendo la gestión en la comunidad. Más que todo gestiona la líder, hacia la alcaldía que presta ese servicio para hacer llegar el agua. No todas las comunidades pueden, ya que hay algunas que están alejadas, entonces las que tienen líder, esta gestiona el trayecto del agua desde donde está hacia la comunidad, para que así puedan beneficiarse los que están alrededor de la comunidad. También lo gestiona a través de la política, tiene que agarrarse de un político para que la puedan llegar a apoyar, porque a veces cuando la líder no está, el agua no llega.

Surge la pregunta sobre por qué una mujer líder en estas comunidades, esto debido a que en la cultura wayúu prevalece la línea materna, la mujer es más importante que el hombre, por lo que toma las decisiones, alegando la capacidad de tener hijos. Por eso es que se dice que la mujer wayúu es símbolo de respeto; por ejemplo, hay mujeres que arrían el agua, recogen la leña, arrían los chivos. En conclusión, es un rol muy importante el que tiene la mujer.

\section{Conclusiones}

Este documento contiene los avances y resultados que se lograron durante la investigación. Por esta razón, las siguientes conclusiones pretenden dar respuesta al problema planteado en la investigación y describir la trascendencia del trabajo investigativo.

Así como en los artículos $3^{\circ}$ y $4^{\circ}$ de la Declaración de las Naciones Unidas sobre los derechos de los pueblos indígenas, 
estos tienen derecho a la libre determinación, también debe tenerse en cuenta el artículo $1^{\circ}$, el cual consagra que los indígenas tienen derecho, como pueblos o como individuos, al disfrute pleno de todos los derechos humanos y las libertades fundamentales reconocidas en la Carta de las Naciones Unidas, la Declaración Universal de Derechos Humanos y las normas internacionales de derechos humanos.

En este mismo sentido, se destacan dos pronunciamientos principales sobre el derecho humano al agua: la Observación General no 15, adoptada por el Comité de Derechos Económicos, Sociales y Culturales en el 2002, y la Resolución 64/292 de la Asamblea General de las Naciones Unidas, reconocida el 28 de julio del 2010. En nuestro país, la Corte Constitucional también se ha pronunciado afirmando que el derecho de toda persona al agua es un derecho fundamental. Pero ante las condiciones ambientales de la Guajira y la escasez de agua podemos concluir que esta situación va en contra de todos los pronunciamientos anteriormente mencionados.

El derecho humano al agua es fundamental e indispensable para concretar otros derechos humanos y/o fundamentales, como lo es el derecho a la salud, y por ende el derecho a la vida, ya que estos no se pueden definir sin un acceso a sistemas de agua potable limpia y al saneamiento.

La escasez de sistemas adecuados de abastecimiento de agua y saneamiento afecta la realización de los demás derechos humanos a las mujeres y niñas wayúus, debido a que obliga a que tengan que realizar largas travesías en busca de recursos hídricos, invirtiendo considerable tiempo y fuerza laboral diariamente, alejándose de un gran número de actividades participativas, lo que supone una desventaja con respecto a los hombres de la comunidad. Es por esto que podemos afirmar 
que a las mujeres y niñas wayúus no se les garantiza el derecho humano al agua.

En cuanto a las políticas públicas propuestas en el departamento de la Guajira para solucionar todos los problemas que acarrea la vulneración del derecho humano al agua, podemos observar que no son más que solo eso: "propuestas", pues los resultados son escasos y muchas veces imperceptibles. Nuevamente, inferimos que no hay garantía por parte del Estado de este derecho, ello sin mencionar que otros problemas, como consecuencia de la falta de agua potable y saneamiento, aún no han sido tocados por el Gobierno. Es el caso del impacto que tiene, desde la perspectiva matrilineal, el desabastecimiento de este preciado líquido, un tema muy valioso que considerar como objeto de debate y para asistir a las mujeres y niñas wayúus en los padecimientos que sufren como consecuencia de la vulneración del derecho humano al agua.

\section{La infinitud}

Talhua, alaüla de Toolünare, nos ha contado que también provenimos de otros mundos... que acumulamos un saber antiguo creador de otros llantos, de otros sueños, de otros pasos... que nuestra sonrisa se extiende en otros labios más allá de esta orilla de la mar. Como nuestra sangre hay un río invisible que nos recorre a todos $[. .$.$] donde viajan$ la misma risa y el mismo silencio. Vito Apushana (2010) 


\section{Referencias}

Apud, A. (2013). Las mujeres y el agua. España: Dirección de Comunicación de Unicef.

Apushana, V.(2010). En las hondonadas maternas de la piel. Bogotá: Ministerio de Cultura.

Bautista,J.(2013). El derecho humano al agua y al saneamiento frente a los Objetivos de Desarrollo del Milenio. Naciones Unidas/ Cepal. Recuperado de http://www.ohchr.org/Documents/ Issues/Water/ContributionsSustainability/ECLAC7.pdf.

Colombia, Congreso de la República (1994). Ley 142 de 1994, que establece el régimen de los servicios públicos domiciliarios. Recuperado de http://www.secretariasenado.gov.co/senado/ basedoc/ley/1994/ ley_0142_1994.html

Comité de Derechos Económicos Sociales y Culturales (cDEsc) (2002). Observación General no 15, El derecho al agua (articulos 11 y 12 del Pacto Internacional de Derechos Económicos, Sociales y Culturales). Recuperado de http://www.rlc.FAo. org/frente/pdf/og15.pdf

Corte Constitucional Colombiana (2007). Sentencia T-270. Magistrado ponente: Jaime Araujo Rentería.

Hernández, R., Fernández, C. y Baptista, P. (2006). Metodología de la investigación. México: McGraw-Hill.

Instituto Interamericano de Derechos Humanos (2006). El módulo Agua, pueblos indigenas, y derechos humanos. Recuperado de http://www.bvsde.paho.org/bvsapi/e/proyectreg2/paises/costarica/agua.pdf)

Ledo, M.C. (2005). Agua potable a nivel de hogares con una dimensión de género: derecho de las mujeres al agua en las ciudades de El Alto, La Paz y Cochabamba. Cochabamba: Ceplag.

Molinares, V.y Echeverría,J. (2011). El derecho humano al agua: Posibilidades desde una perspectiva de género. International 
Law, (19),269-301. Recuperado de http:/www.scielo.org.co/ scielo.php?script=sci_arttext\&pid=S169281562011000200 009\&lng=en\&tlng=es

Ojeda, G. (2011). La mujer wayuu. Recuperado de http://www. achijirawaa.co/node/652

Ordeñana, T. (2000). Los derechos de las mujeres son derechos humanos. Revista Jurídica. Facultad de Derecho de la Universidad Católica de Guayaquil. Recuperado de http://www. revistajuridicaonline.com/index.php?option=com_content \&task=view\&id=94\&Itemid=39

Organización de las Naciones Unidas, Asamblea General (2010). Resolución A/64/L.63/Rev.1. Recuperado de http://daccess-dds ny.un.org/doc/undoc/LTD/N10/464/67/PDF/ N1046467.pdf?OpenElement

Organización de las Naciones Unidas (2011). El agua más preciada de las mujeres wayuu. Recuperado de http://www.un.org/ content/es/_vidout/video5.shtml

Pulgarín, C. (1997). La mujer wayuu. El Tiempo. Recuperado de http://www.eltiempo.com/archivo/documento/MAM577970

Quigua, A. (2011). Derecho al agua-Jurisprudencia Constitucional en Colombia. Bogotá: Polo Democrático Alternativo.

Ramírez, G. et al. (2009). Diagnóstico del cumplimiento del derecho bumano al agua en Colombia. Bogotá: Defensoría del Pueblo. Tamayo, M. (2003). Metodología formal de la investigación cientifica. Bogotá: Comes. 



\title{
Desafíos conceptuales del bloque constitucional
}

\author{
María Alejandra Mercado Donato* \\ Julieth Tatiana Rojas Pinzón**
}

\section{Resumen}

Uno de los problemas centrales del constitucionalismo contemporáneo es la convivencia entre normas de origen local y normas internacionales y la adecuada articulación de estas. La teoría constitucional ha intentado ofrecer herramientas teóricas para dar cuenta de este fenómeno. Una de ellas es la teoría del bloque constitucional, de acuerdo con la cual existen normas jurídicas que, aun cuando no se pueden asociar a ninguna cláusula de la Constitución formal, son relevantes al momento de decidir las cuestiones constitucionales. Sin embargo, no está claro cuál es el problema que en concreto se

* Estudiante de III semestre de Derecho en la Universidad de La Sabana, Cundinamarca, Colombia. Miembro del Semillero de Investigación "Fundamentos Filosóficos del Derecho Constitucional”. Correo electrónico: mariamedo@ unisabana.edu.co.

** Estudiante de III semestre de Derecho en la Universidad de La Sabana, Cundinamarca, Colombia. Miembro del Semillero de Investigación "Fundamentos Filosóficos del Derecho Constitucional”. Correo electrónico: juliethropi@ unisabana.edu.co. 
pretende abordar con la teoría del bloque constitucional. En este escrito sostenemos que la noción de bloque constitucional apunta a tres cuestiones distintas: 1) la determinación de fuentes o documentos jurídicos relevantes, 2) la definición de criterios de pertenencia de tales fuentes al ordenamiento jurídico-constitucional y 3) la definición de cuáles de esos documentos jurídicos resultan aplicables para resolver los casos constitucionales.

\section{Introducción}

\section{Un caso hipotético}

El Gobierno Nacional y un grupo guerrillero firmaron un acuerdo de paz, luego de décadas de conflicto armado en el país. En los meses siguientes a la firma del acuerdo, unos excombatientes guerrilleros fueron acusados de violación de derechos humanos por hechos ocurridos durante el periodo de preacuerdo de paz. Estas personas se entregaron a la justicia en el momento en que se firmó el acuerdo y fueron acusadas por la Fiscalía por genocidio y tortura.

De acuerdo con un tratado sobre derechos humanos, firmado y ratificado por Colombia, está prohibida la amnistía en caso de graves violaciones contra los derechos humanos y el derecho internacional humanitario, y en especial se exige que las víctimas y sus familiares puedan tener justicia por las violaciones cometidas (Tratado P). En otro tratado, por su parte, se establece que los Estados tienen derecho a la autodeterminación y en particular a definir la forma como resuelven sus problemas políticos (Tratado $\mathrm{P}$ ). Un tribunal internacional con jurisdicción sobre el Estado colombiano, al pronunciarse sobre un acuerdo similar en otro país del continente, aceptó la amnistía a favor de un grupo guerrillero con el propósito 
de que el país pudiera entrar en una nueva etapa de paz y tranquilidad en su sociedad (Decisión R). Por último, una ley estatutaria expedida por el Congreso de la República establece penas sustitutas para los miembros de los grupos guerrilleros que reconocieron crímenes.

En este contexto, un tribunal, conformado por los jueces Justino, Ulpiano y Pompeyo debía decidir sobre la imposición de una pena privativa de prisión a los integrantes del grupo guerrillero. El juez Justino, considerando que todos aquellos acuerdos internacionales que versen sobre derechos humanos, referidos por las cláusulas de reenvío, hacen parte del bloque constitucional (BC), vota por que se condene a los procesados. Sostiene que el Tratado $\mathrm{P}$ es vinculante en tanto hace parte del вс y además afirma que ni la jurisprudencia, ni la ley estatutaria son vinculantes, pues no hacen parte de la Constitución colombiana.

El juez Ulpiano, tomando la postura de que el вc lato sensu consiste en aquellas normas que no tienen rango constitucional, pero configuran parámetros para analizar la validez de las normas jurídicas, considera que debe absolverse a los condenados, puesto que el acuerdo busca, a través de lo pactado por la partes, conseguir la paz en la sociedad. Agrega que el Tratado $\mathrm{P}$, de acuerdo con jurisprudencia de la Corte Interamericana de Derechos Humanos, resulta aplicable solo para aquellos casos de autoamnistías en situaciones de transición de regímenes dictatoriales a democráticos. Considera asimismo que en el caso de los integrantes del grupo guerrillero, debe aplicarse la jurisprudencia del tribunal de $\mathrm{P}$, que acepta la amnistía a un grupo guerrillero a favor de la consecución de la tan anhelada paz nacional. Además, afirma que la ley estatutaria hace parte del вс y se constituye en referente normativo obligatorio para esta decisión. 
El último juez, Pompeyo, niega que el Tratado $\mathrm{P}$ tenga jerarquía constitucional, piensa que la Constitución está conformada exclusivamente por el documento de 1991 y sus reformas y que los tratados aludidos son criterios auxiliares de interpretación, y que por tanto su aplicación no es obligatoria. Concluye que se debe condenar a los acusados por no respetar el derecho a la vida consagrado en el artículo $11^{\circ}$ de la Constitución Política y que la exigencia de justicia en estos casos es un derecho inherente a la persona humana en los términos del artículo $94^{\circ}$ de la Constitución.

\section{Planteamiento del problema}

Uno de los problemas centrales del constitucionalismo contemporáneo es la convivencia entre normas de origen local y normas internacionales y su adecuada articulación. En el caso hipotético planteado se evidencia que la forma como se comprendan estas relaciones afecta la toma de decisiones, haciendo que un mismo juez pueda fallar de formas diversas frente al mismo caso concreto.

Desde décadas atrás se viene reconociendo que el concepto moderno de Constitución no es suficiente para dar cuenta de estas relaciones. Por ello la teoría constitucional ha intentado ofrecer herramientas teóricas que sirvan para responder a estos cambios. Una de ellas es la teoría del BC, de acuerdo con la cual existen normas jurídicas que, aun cuando no se pueden asociar a ninguna cláusula de la Constitución formal, son relevantes al momento de decidir las cuestiones constitucionales.

La Corte Constitucional ha empleado la teoría del вс para resolver diferentes cuestiones. Sin embargo, a pesar de algunos intentos de sistematización y precisión conceptual, el panorama sigue siendo confuso: ¿qué quiere decir que $\mathrm{X}$ pertenezca a BC? 
¿Significa que X hace parte de la Constitución? ¿Significa que es aplicable en casos constitucionales? ¿Cuáles son los criterios para determinar si $\mathrm{X}$ es вс? ¿Cómo puede ser que existan normas que no tengan jerarquía constitucional pero que sí determinen la validez constitucional de otras normas? ¿Cuál es la relevancia de distinguir entre вс lato sensu у вс stricto sensu? ¿A partir de qué criterios se hace esta diferenciación? Estos, entre otros problemas, solo pueden resolverse una vez se defina conceptualmente la noción de BC y su función normativa.

De acuerdo con esto el problema de investigación que abordamos en este trabajo puede formularse mediante la siguiente pregunta: ¿Cuál es el lugar del BC en el concepto de Constitución y cuáles son sus relaciones con el resto del ordenamiento jurídico? En otros términos, lo que se pretende determinar son las propiedades conceptuales de la noción de BC y de esta manera diferenciarlo de fenómenos similares. Entendemos que, como se planteó en el caso hipotético, determinar tales propiedades es una tarea esencial para una adecuada comprensión e implementación de las relaciones entre el derecho internacional y el derecho constitucional.

De acuerdo con lo anterior, en este trabajo se propone 1) señalar las deficiencias en la conceptualización de la noción de $\mathrm{BC}$ en la jurisprudencia de la Corte Constitucional y 2) delimitar la función del bloque constitucional en relación con la identificación de normas jurídicas, su pertenencia y aplicabilidad.

\section{Diseño metodológico}

Mediante una metodología analítico-sintética, en primer lugar se analiza la jurisprudencia de la Corte Constitucional en materia de bloque constitucional, con el objeto de identificar los elementos centrales de dicho bloque y la forma como ha sido 
empleado por esta corporación. Para el análisis del concepto de BC se partió del trabajo de sistematización de Uprimny (2005) y se estudiaron las sentencias de la Corte Constitucional que, posteriormente a dicho trabajo, emplearan explícitamente las nociones de $\mathrm{BC}$ en sentido lato y en sentido estricto. Luego, para dar cuenta del carácter sintético de la investigación, se reconstruyeron los elementos analizados en función de las nociones de pertenencia y aplicabilidad de las normas jurídicas planteadas por Raz (1991), Bulygin (1991), Rodríguez y Vicente (2009) y Navarro y Rodríguez (2014).

El objetivo general de la investigación consiste en comprender el concepto de BC en función de las nociones de pertenencia y aplicabilidad de las normas jurídicas, con el propósito de dar precisión conceptual al empleo de esta noción en la jurisprudencia constitucional. Para ello se plantearon los siguientes objetivos específicos: 1) examinar la jurisprudencia de la Corte Constitucional en aquellas decisiones en las que emplee expresamente las nociones de $\mathrm{BC}$ en sentido estricto y en sentido lato; 2) analizar el concepto de Constitución para definir el lugar de la noción de $\mathrm{BC} ; \mathrm{y} 3$ ) reconstruir las nociones de $\mathrm{BC}$ en sentido estricto y en sentido lato, de acuerdo con los elementos jurisprudenciales identificados y las nociones de pertenencia y aplicabilidad.

Este trabajo constituye un avance de esta investigación. En la primera parte de los resultados mostramos las tesis principales que identificamos en la jurisprudencia constitucional. En la segunda parte, en correspondencia con el segundo objetivo, ubicamos el concepto de $\mathrm{BC}$ y presentamos la importancia de plantear un marco teórico en función de los conceptos de pertenencia y aplicabilidad que permita superar las perplejidades en la comprensión y aplicación del вС. 


\section{La noción de bloque constitucional en la jurisprudencia de la Corte Constitucional}

El desarrollo jurisprudencial colombiano en materia de BC, como bien lo señala Uprimny (2005), ha sido lento y complejo; ha sufrido varios cambios a través del tiempo, especialmente después de la Constitución de 1991, puesto que en ella se establece el reconocimiento de los tratados internacionales en materia de derechos humanos (cláusulas de reenvío). ${ }^{1}$

La primera etapa es la comprendida entre 1992 y 1994, en la cual se dan los primeros e incipientes acercamientos al BC por parte de la Corte Constitucional, dejando como resultado el reconocimiento del Pacto de Derechos Económicos, Sociales y Culturales como parte del ordenamiento jurídico colombiano, y reconociéndolo como aplicable (Sentencia T-426 de 1992). Debido a ello es posible deducir que el concepto presente durante aquel periodo era el de $\mathrm{BC}$ entendido como tratados firmados y ratificados por Colombia, y usados como método interpretativo aplicable dentro de la jurisprudencia nacional (Uprimny, 2005).

En la segunda etapa (1995 a 1996) se incorpora por primera vez el término "bloque constitucional", creado inicialmente por el Consejo Constitucional francés, en la Sentencia C-225 de1995, y que se define como las normas de carácter humanitario que no pueden dejar de aplicarse en estados de excepción, gracias a la existencia del artículo 93 de la Carta Política (Uprimny, 2005).

1 Gutiérrez Beltrán (2007) hace un estudio más general del bloque constitucional en Colombia. Sin embargo, hemos decidido enfatizar en el estudio de Uprimny dado que incluye un enfoque iusteórico explícito en relación con la diferencia entre jerarquía constitucional y aplicabilidad constitucional, que resulta más adecuado para los efectos de este trabajo. Pueden verse también los trabajos de Olano (2005) y Rey Cantor (2006). 
Finalmente, desde 1997 se hacen las primeras aproximaciones a una sistematización doctrinal para precisar los alcances y metodologías que debían implementarse en los casos en que se usara el вc. Del mismo modo, se lleva a cabo una delimitación enfocada a determinar las disposiciones que harían parte de este, así como una expansión normativa con respecto a la recepción de nuevos materiales jurídicos internacionales que recen sobre derechos humanos, como el convenio con la Organización Internacional del Trabajo (OIT) y la jurisprudencia foránea (Uprimny, 2005).

Dados los diferentes matices de la noción de Bc, la jurisprudencia constitucional ha distinguido entre $\mathrm{BC}$ stricto sensu у вс lato sensu. El primero incluye al preámbulo, los tratados internacionales firmados y ratificados por Colombia en materia de límites territoriales, derecho humanitario y derechos intangibles, derechos reconocidos por la Carta política que también sean reconocidos en dichos acuerdos, y el articulado constitucional. El segundo agrega a los elementos anteriormente mencionados, las leyes estatutarias y orgánicas nacionales. ${ }^{2}$

En todo caso, y para lo que en concreto importa a este trabajo, de acuerdo con la sistematización de Uprimny, en la conceptualización del вс se debe diferenciar entre 1) las normas de rango constitucional, 2) los parámetros de constitucionalidad de las leyes y 3) las normas que son constitucionalmente relevantes en un caso específico; es decir, de acuerdo con este autor, la noción de вс es ambigua y se refiere a objetos distintos aun cuando relacionados. Primero se refiere a las normas

2 El concepto de bloque constitucional, como se verá más adelante, no ha sido nada pacífico en la jurisprudencia constitucional, puesto que ha tenido distintas conceptualizaciones a través del tiempo. 
que hacen parte de la Constitución, segundo a normas que funcionan como parámetros para efectuar el juicio de constitucionalidad de las leyes, y tercero a normas que — sin ser parte de la Constitución ni funcionar como parámetro en los juicios de constitucionalidad - resultan relevantes para resolver los casos concretos. Uprimny concluye que la naturaleza de la noción no es nítida, el mecanismo de incorporación de las normas al вс no es claro, ni tampoco lo son las normas y principios que lo integran.

A pesar de las conclusiones y recomendaciones de Uprimny, la jurisprudencia posterior de la Corte Constitucional no ha sido clara en el empleo de la noción de BC. Así, en la Sentencia C-047 de 2006, en la cual se debía determinar si la posibilidad de apelar una sentencia absolutoria en materia penal violaba el principio del non bis in idem, se explicó que la apelación era parte del mismo proceso, puesto que es una segunda instancia y no hay tratados internacionales de derechos humanos que la prohíban. Se agregó que el derecho a impugnar una sentencia condenatoria y la garantía de non bis in idem no están previstos de manera expresa entre aquellos derechos que no son susceptibles de ser suspendidos durante un estado de excepción, esto de acuerdo con el Pacto Internacional de Derechos Civiles y Políticos y la Convención Americana de Derechos Humanos.

Con base en las anteriores consideraciones, la Corte declaró exequibles los apartes citados, pues dicha apelación — considera la Corporación - no vulnera el principio en mención. En esta sentencia se sostuvo que la Convención es un criterio obligatorio para la constitucionalidad (validez) de las normas jurídicas. Para explicar en qué sentido tales normas (como la Convención) se constituyen en criterios obligatorios de constitucionalidad, la Corte recurrió a la noción de вс, recordando la distinción entre вС stricto sensu y lato sensu. Por stricto sensu 
entendió aquellas normas que tienen jerarquía constitucional, y por lato sensu aquellas normas que si bien carecen de rango constitucional, configuran parámetros para analizar la validez de las normas jurídicas. En este mismo sentido agregó:

Así, de acuerdo con la jurisprudencia constitucional, integran el bloque de constitucionalidad en sentido lato: (i) el preámbulo, (ii) el articulado de la Constitución,(iii) algunos tratados y convenios internacionales de derechos humanos (C.P. art.93), (iv) las leyes orgánicas y, (v) en algunas ocasiones, las leyes estatutarias. (Sentencia C-047 del 2006, p. 21)

La Corte sostiene que el вс en sentido lato, el cual configura parámetros de análisis de validez de las normas, y que se supone no tiene rango constitucional, está integrado por el contenido formal de la Constitución, es decir, el preámbulo y el articulado (que son disposiciones y se suponen Constitución en sentido formal); además lo integran tratados que versen sobre derechos humanos, las leyes orgánicas y las estatutarias. De lo dispuesto se desprenden dos problemas evidentes: el primero es el planteamiento de si las disposiciones constitucionales son $\mathrm{BC}$, lo que representaría una contradicción evidente de la Corte, ya que la diferenciación entre Constitución en sentido material y Constitución en sentido formal dejaría de existir, para transformarse todo en material constitucional. El segundo es que al clasificar los tratados y convenios internacionales en el вс lato sensu, estos dejarían de tener rango constitucional y pasarían a ser meros parámetros de configuración del análisis de la validez de normas jurídicas internas.

Dos años después, en la Sentencia C-617 del 2008, la Corte resolvió una demanda de constitucionalidad de los artículos $362^{\circ}$ (parcial) y $432^{\circ}$, numeral $2^{\circ}$, del Código Sustantivo del 
Trabajo, en los cuales se definen los requisitos mínimos que necesita una agremiación sindical para ser reconocida como tal, así como las condiciones formales que deben cumplir las personas que, llegado el caso, representen a dicha agremiación frente a conflictos colectivos. Los demandantes consideraron que con ello se violaban el preámbulo y el artículo $2^{\circ}$ de la Constitución, así como el numeral $2^{\circ}$ del artículo $3^{\circ}$ del Convenio 87 de la оiт. Por lo tanto, fue competencia de la Corte "determinar inicialmente si el referido convenio sirve como parámetro para apreciar la constitucionalidad de la disposición examinada"(Sentencia C-617 del 2008, p. 14).

Para aclarar la aplicabilidad del Convenio 87 de la oit en el caso expuesto por las demandantes, la Corte definió el concepto de вС e hizo distinción entre lato sensu y stricto sensu. En este sentido sostuvo:

[...] el mencionado bloque reúne un conjunto de normas y principios que, aún cuando no aparecen formalmente en el texto constitucional, se entienden integrados a la Constitución y hacen parte de ella. Junto a esta noción estricta, la jurisprudencia constitucional ha forjado una noción amplia, según la cual el bloque "estaría compuesto por todas aquellas normas de diversa jerarquía, que sirven de parámetro para llevar a cabo el control de constitucionalidad de la legislación”. (Sentencia C-617 del 2008, p. 14)

Hasta ese punto la Corte, al parecer, mantenía los conceptos que había planteado en sentencias anteriores, especialmente en la Sentencia C-047 del 2006, en donde definió вс stricto sensu como todas las normas aplicables al ordenamiento jurídico colombiano y que no hacían parte de la Constitución en sentido formal, pero tenían rango constitucional, y lato 
sensu como todas las normas que servían como criterio interpretativo, aun cuando no tuvieran rango constitucional, como es el caso de las normas estatutarias.

A este concepto ya bien conocido de BC la Corte (2008) agregó en la misma sentencia lo siguiente:

[...] la determinación de los elementos que conforman el bloque de constitucionalidad, ya sea en el sentido amplio o en su sentido estricto, así como la definición del rango de cada uno corresponde a la Corte Constitucional y, en consecuencia, su inclusión y el alcance de esa inclusión dependen del examen adelantado por la Corporación en cada caso, así como de las materias previstas en las disposiciones o en el respectivo tratado o convenio. (Sentencia C-617 del 2008, p. 15)

La Corte incluyó un nuevo presupuesto al concepto de BC, y es que es ella misma la competente para definir, en cada caso, cuáles materiales hacen parte del BC y cuáles no, así como el sentido en el que pertenecen (lato o stricto sensu), lo que tiene un claro impacto en el rango que van a tener dichas disposiciones.

Posteriormente, en la Sentencia C-228 del 2009, la Corte se volvió a pronunciar sobre el $\mathrm{BC}$, a la luz de una demanda al artículo $3^{\circ}$ de la Ley 1101 del 2006, mejor conocida como Ley General de Turismo, donde se determinan los aportes de la contribución parafiscal para la promoción del turismo, por considerar que se viola el artículo $29^{\circ}$ del Estatuto Orgánico del Presupuesto (Decreto 111 de 1996), que a su vez corresponde al artículo $2^{\circ}$ de la Ley 225 de 1995, además de vulnerarse los artículos 95, 363 y 150 de la Carta Política. La Corte analizó el concepto de $\mathrm{BC}$ para determinar si dicho 
estatuto hacía parte de él y aplicarlo al caso concreto de esta demanda. Así, definió que

[...] forman parte del bloque de constitucionalidad aquellas reglas y principios que, sin figurar expresamente en la Carta, tienen rango constitucional (bloque de constitucionalidad en sentido estricto) o al menos representan parámetros de constitucionalidad (bloque de constitucionalidad en sentido lato) que permiten controlar la constitucionalidad de las leyes y de las normas de inferior jerarquía, por cuanto la propia Constitución, por medio de cláusulas de remisión, confiere fuerza jurídica especial a esas reglas y principios. (Sentencia C-228 del 2009, p. 28)

Fue así como la Corte trató de mantener su precedente con respecto al вс, especialmente el de la Sentencia C-047 del 2006, donde el sentido lato es un criterio interpretativo, sin rango constitucional, y el sentido estricto son disposiciones jurídicas distintas a la Constitución que gozan del mismo rango dentro del ordenamiento jurídico nacional. Ambos son parámetros de legitimidad constitucional, aunque no tienen el mismo rango dentro de la pirámide normativa. Por lo tanto, "todas las normas que integran el bloque de constitucionalidad son parámetros necesarios e indispensables para el proceso de creación de la ley" (p. 28) y se facilita el control de constitucionalidad. Asimismo, la Corte trajo a colación la importancia de la existencia de cláusulas de remisión para el concepto de $\mathrm{BC}$, como leyes legitimadoras e integradoras de tratados internacionales que versen únicamente sobre temas de derechos humanos.

La sentencia no solo recoge aspectos mencionados en la jurisprudencia anterior, además menciona que las leyes 
estatutarias hacen parte del $\mathrm{BC}$, tienen rango constitucional y se usan como método de acercar la Constitución a las leyes ordinarias y poder hacer un mejor control de constitucionalidad de ellas.

Como la Corte misma ha reconocido, "entender que el respeto de las normas de rango legal para el ejercicio de dicho control, es un tópico que a primera vista parecería contradictorio" (Sentencia C-047 del 2006, p. 29), puesto que el objeto mismo del control constitucional, y el uso del вс en este, es el de hacer un juicio de adecuación entre la Constitución y las demás leyes. Sin embargo, para la Corte es claro que lograr hacer dichos juicios en algunos casos concretos no es tarea fácil, especialmente cuando las disposiciones constitucionales son demasiado amplias y lejanas del contexto de aplicación de las leyes, y es en este marco en que la Corte considera que una ley estatutaria puede ser entendida como parte del BC, pues funciona como puente de comunicación entre la Constitución y la ley ordinaria:

Estas leyes que permiten determinar el alcance pleno de las normas constitucionales y de esta forma apreciar en un caso concreto la constitucionalidad de otra ley enjuiciada cumplen funciones de parámetro complementario o de norma interpuesta. (Sentencia C-047 del 2006, p. 30)

Adicionalmente, la ley estatutaria cumple con presupuestos constitucionales de carácter formal, los cuales hacen que exista una relación diferente entre leyes ordinarias entre sí y con leyes estatutarias, puesto que las primeras no pueden derogar en ningún caso las segundas, mientras que el proceso contrario puede suceder sin inconvenientes. Asimismo, las leyes estatutarias tienen un proceso de expedición diferente 
al de las leyes ordinarias. Todo lo anterior deriva en que, en algunos casos, "[...] La norma objeto de control (B) se compara con la norma constitucional (A), y a su vez esta última adquiere su verdadero alcance a partir de la consideración de la norma legal orgánica o estatutaria (C)" (Sentencia C-047 del 2006, p. 30).

La Corte hace una nueva interpretación del Bc, que complementa el concepto que se había desarrollado, especialmente en lo referente al lato sensu, incluyendo las leyes estatutarias como parte del bloque en este sentido. Como la Corte misma dijo:

[...] las referidas leyes orgánica y estatutaria pueden ser utilizadas como parámetro de control de constitucionalidad, en tanto (i) determinan en algunos casos el alcance real de las normas constitucionales y (ii) su contenido, según la Constitución, enmarca los límites a los que deben ceñirse otras leyes, lo cual configura la exigencia de un trámite especial en ciertos temas (trámite de ley orgánica o estatutaria), que debe ser respetado so pena de vulnerar los principios constitucionales que la contienen. (Sentencia C-047 del 2006, p. 30)

El análisis de las sentencias deja claro la existencia de ambigüedad en la noción de вс con respecto a la identificación y aplicación del derecho. Asimismo, se plantea que la Convención Interamericana representa un criterio obligatorio para la constitucionalidad de las normas, mientras que en lo referente al BC en stricto sensu, parece haber precisión en que consiste en normas de jerarquía constitucional, lo que quiere decir que es un conjunto de normas que, si bien no aparecen en el texto, se entienden integradas a la Constitución y hacen parte de ella. 
Del вс en amplio lato se dice que lo conforman todas aquellas normas de diversa jerarquía que sirven de parámetro para el control constitucional, lo cual indica que no tendrían rango de constitucionalidad, al menos, no todas ellas. La misma Corte, en las sentencias del 2009, afirma que la determinación de los elementos que forman parte del $\mathrm{BC}$ depende del análisis que haga ella después en cada caso, y esto último podría acarrear inseguridad jurídica, al desconocerse qué debe ser acatado o no por los jueces en lo referente al вc lato sensu.

Del análisis de la Corte en la primera sentencia objeto de estudio, donde se hace mención de la Constitución en sentido formal como parte del вс en amplio sentido, о lato sensu, se infiere que la Corte da a entender por ello todo el material constitucional que no sea tratado internacional de derechos humanos. En este orden de ideas, si el BC es Constitución en sentido material, que se diferencia del formal por no estar contenido en los textos constitucionales, si el texto se entendiera como material constitucional, no habría necesidad de hacer la diferenciación y toda la Constitución (texto y demás material) sería material jurídico relevante.

De las sentencias también se desprende que el BC en sentido lato consiste en aquellas normas que aun cuando no tienen rango constitucional, configuran parámetros para analizar la validez de las normas jurídicas. Entonces, ¿`a qué hacen referencia estos parámetros?, ¿qué significan? Si son configurados para analizar la validez de las normas jurídicas, podrán consistir en reglas para determinar el alcance de las normas constitucionales, lo que quiere decir que conforman criterios de interpretación, que marcan límites a los límites a los que deben ceñirse estas normas.

En definitiva, de acuerdo con lo dicho se pueden identificar las siguientes tesis sobre la noción de BC: 
- Tesis 1: en la conceptualización del вс se debe diferenciar entre 1) las normas de rango constitucional, 2) los parámetros de constitucionalidad de las leyes y 3) las normas que son constitucionalmente relevantes en un caso específico (Uprimny).

- Tesis 2: el вс está conformado por el conjunto de normas que constituyen un criterio obligatorio para la validez de las normas jurídicas (Sentencia C-047 del 2006).

- Tesis 3: se entiende por BC stricto sensu aquellas normas que tienen rango constitucional, y por lato sensu aquellas normas que no tienen rango constitucional, pero sirven como criterio de validez de las normas jurídicos (sentencias C-047 del 2006, C-617 del 2008 y C-228 del 2009).

- Tesis 4: la Corte Constitucional es la que determina los elementos que comprenden el Bc, tanto en stricto como en lato sensu, y el alcance de cada elemento será determinado por ella en cada caso del que deba conocer (Sentencia C-617 del 2008).

\section{Constitución en sentido material: ¿¿cuál es el lugar del bloque constitucional?}

Las dinámicas de la globalización suponen retos a la comprensión tradicional de la Constitución y sus relaciones con el derecho internacional. No solo la Constitución funciona más allá de las fronteras nacionales, sino que el derecho internacional suele desarrollar funciones constitucionales. Estas características han llevado a algunos autores a formular la existencia de un derecho constitucional transnacional, caracterizado por el desarrollo de arreglos constitucionales transnacionales, el empleo de decisiones judiciales en diferentes contextos (v.gr., 
diálogos y precedentes internacionales) y la definición de normas y parámetros internacionales comunes a constituciones de diferentes Estados (Yhe y Chang, 2008).

De acuerdo con esto, una de las características principales de la teoría constitucional contemporánea es que debe dar cuenta de las dinámicas transnacionales de las fuentes jurídicas, y dentro de esto explicar la cuestión acerca de la identificación de la Constitución. Para esta tarea se deben investigar los criterios que permitan establecer el papel de las normas jurídicas en un contexto en el que las fuentes nacionales son insuficientes. ${ }^{3}$

En el marco de esta problemática, la dogmática constitucional ha desarrollado la distinción entre Constitución en sentido formal y Constitución en sentido material. ${ }^{4}$ La primera es el documento promulgado por el acto constituyente o sus reformas; en otras palabras, es el documento escrito aprobado mediante un acto constituyente (primario o secundario). Por ello, en aquellos Estados que cuentan con una Constitución escrita no debería existir mayor dificultad para identificar la Constitución en sentido formal. En contraste, la identificación de la Constitución en sentido material no es una tarea igual de sencilla. La dificultad obedece a que la Constitución material apunta a dos cuestiones distintas: la primera referida

3 Sobre la noción de bloque constitucional y la importancia de las relaciones con los ordenamientos jurídicos nacionales, véase Ramelli (2004), quien aborda el tema desde un enfoque internacionalista.

4 Con respecto a la relación entre Constitución en sentido material y bloque constitucional, véase Bidart (1995) y Rey Cantor (2006). En todo caso, debe tenerse en cuenta que esta distinción fue plantada por Kelsen (1958) y ha sido empleada en distintos contextos para justificar la existencia de normas constitucionales más allá de los documentos constitucionales. Véase, por ejemplo, la noción de Constitución sedimentaria en Friedman y Smith (1998), o la de la distinción entre Constitución histórica y práctica constitucional en Nino (1992). 
a la identificación de los documentos jurídicos relevantes y la segunda a la determinación de las normas jurídicas.

La noción de Constitución en sentido material se refiere, de una parte, al conjunto de documentos (y no solamente la Constitución formal) que conforman la Constitución, y, de otra parte, al conjunto de normas que hacen parte de la Constitución. Esta diferencia se entiende mediante la conocida distinción entre disposiciones normativas y normas. Las primeras son actos lingüísticos de las autoridades jurídicas que crean o reconocen normas jurídicas, en tanto que las segundas suelen entenderse como el enunciado normativo y su significado. Las normas son el significado de las disposiciones que se refieren al otorgamiento de poderes o a la definición de un caso como jurídicamente prohibido, obligatorio o facultativo. De acuerdo con esto, la Constitución en sentido material puede referirse, por una parte, al conjunto de disposiciones constitucionales, y por la otra, al conjunto de normas jurídicas constitucionales. $^{5}$

Teniendo en cuenta lo anterior, la cuestión acerca de cuál es el lugar de la noción de BC en el concepto de Constitución debe apuntar, en un primer momento, a la definición de si es un problema referido a la identificación de documentos o a la determinación de normas. De acuerdo con lo estudiado en el punto anterior, la cuestión del вс de la forma, como se ha planteado en la jurisprudencia constitucional, se refiere a la identificación de documentos jurídicos relevantes. En otras palabras, el problema del вс constitucional es una cuestión relativa a los criterios de identificación de documentos o materiales jurídicos

5 Esta distinción puede verse en Atienza y Manero (1996, pp. 46-76), Rodríguez (2002), Alchourron y Bulygin (1974) y Bulygin (2004). 
relevantes, y no una tarea de interpretar o identificar las normas jurídicas relevantes para resolver un caso.

Por otra parte, la teoría jurídica diferencia entre pertenencia de la norma a un ordenamiento jurídico y aplicabilidad de esta. Así, una norma jurídica pertenece a un ordenamiento jurídico cuando, de acuerdo con los criterios de identificación existentes, se puede afirmar que hace parte de él. Por otra parte, una norma es aplicable cuando el derecho exige que los órganos decisores le otorguen autoridad con respecto a un caso. En función de las relaciones entre pertenencia y aplicabilidad, existe acuerdo en torno a que los ordenamientos constitucionales son sistemas abiertos, y por lo tanto otorgan valor normativo a disposiciones jurídicas de forma independiente a su pertenencia (Bulygin, 2001; Raz, 1991).

Como consecuencia de esta distinción, no existe una conexión necesaria entre aplicabilidad y pertenencia de una norma a un sistema jurídico; es decir, una norma puede pertenecer a un sistema jurídico y no ser aplicable (v.gr., una disposición jurídica inconstitucional que no ha sido declarada inexequible con efectos erga omnes). Asimismo, una norma puede ser aplicable sin pertenecer al ordenamiento jurídico (v. gr., una norma derogada con efectos ultractivos). En definitiva, la cuestión determinante es si las nociones de pertenencia y aplicabilidad son distintas y, por tanto, obedecen a criterios distintos. ${ }^{6}$

En suma, el problema del BC constitucional obedece a la cuestión de qué documentos jurídicos a) pertenecen al ordenamiento jurídico constitucional y b) qué documentos jurídicos resultan aplicables para resolver los casos constitucionales. De acuerdo con lo primero, la noción de $\mathrm{BC}$ debe ofrecer una

6 Este asunto ha sido analizado con respecto a las normas de derecho internacional por Rodríguez y Vicente (2011). 
respuesta a la determinación de los criterios para identificar los materiales jurídicos (las disposiciones jurídicas) que pertenecen a la Constitución. De acuerdo con lo segundo, dicha noción debe ofrecer una explicación de los criterios que hacen que documentos externos al ordenamiento constitucional sean aplicables.

En términos de Hart (1963, 1994), el problema de la pertenencia depende de la noción de regla de reconocimiento, la cual establece los criterios últimos de identificación de normas pertenecientes a un sistema jurídico determinado. Lo que identifica a un sistema jurídico — siguiendo con Hart - es que este, además de establecer las acciones que los agentes deben o no realizar (reglas primarias), contiene normas necesarias para definir, aplicar y modificar tales deberes (reglas secundarias).

Para la existencia del ordenamiento jurídico resulta determinante la noción de aceptación de la regla de reconocimiento, por ejemplo, la práctica de usar de manera compartida los criterios de validez jurídica incorporados a la regla de reconocimiento, y criticar a quienes se aparten de ella. Sin embargo, como se dijo, no existe una conexión necesaria entre pertenencia y aplicabilidad. Existen normas que aun cuando no pertenecen al ordenamiento jurídico, no pueden ser ignoradas por los jueces al momento de justificar las decisiones. La característica central que tiene como consecuencia la distinción entre pertenencia y aplicabilidad, es que los ordenamientos jurídicos son necesariamente abiertos, es decir, tienen una naturaleza abierta a consideraciones normativas extrasistemáticas (Raz, 1991; Navarro y Rodríguez, 2014).

De acuerdo con lo anterior, no parecen existir dudas en torno a que una adecuada explicación de la noción de $\mathrm{BC}$ depende de la forma como se definan los criterios de pertenencia 
y de aplicabilidad, así como de la forma en que se conceptualicen las diferencias entre tales conceptos. La perplejidad que generan las inconsistencias entre las tesis identificadas en el punto anterior de este trabajo, es una buena muestra de la necesidad de hacer estas precisiones conceptuales.

\section{Conclusiones}

De acuerdo con el análisis de la jurisprudencia de la Corte Constitucional, se identificaron las siguientes tesis: 1) el вс está conformado por el conjunto de normas que constituyen un criterio obligatorio para la validez de las normas jurídicas; 2) el вс stricto sensu lo constituyen aquellas normas que tienen rango constitucional, en tanto que por вс lato sensu se entienden aquellas normas que no tienen rango constitucional, pero sirven como criterio de validez de las normas jurídicas; 3) la Corte Constitucional es la que determina los elementos que comprenden el вс, tanto stricto como lato sensu, y es ella la que determina el alcance de cada elemento en cada caso del que deba conocer.

Estas tesis no dan respuesta acerca de la naturaleza de la noción de вс ni tampoco con respecto a los criterios para definir cuándo una norma se constituye en criterio obligatorio de validez o en qué sentido se puede afirmar que una norma que no hace parte del ordenamiento constitucional pueda constituirse en criterio de validez de las normas jurídicas.

La propuesta de Uprimny de distinguir entre 1) normas de rango constitucional, 2) parámetros de constitucionalidad de las leyes y 3 ) normas que son constitucionalmente relevantes en un caso específico (Uprimny), no ha sido desarrollada y, en consecuencia, no ofrece un marco conceptual adecuado para comprender los problemas abordados con la noción de BC.

De acuerdo con los resultados que arroja el avance de nuestra investigación, una adecuada comprensión de estos 
aspectos lleva a afirmar que el problema del вс debe ser abordado desde distintos niveles de análisis. Por una parte, la cuestión del BC, como se ha planteado en la jurisprudencia constitucional, se refiere a la identificación de documentos jurídicos relevantes. En otras palabras, el problema del вс constitucional es una cuestión relativa a los criterios de identificación de documentos o materiales jurídicos relevantes y no una tarea de interpretar o identificar las normas jurídicas relevantes para resolver un caso. En síntesis:

1) El problema del $\mathrm{BC}$ constitucional obedece a la cuestión de qué documentos jurídicos a) pertenecen al ordenamiento jurídico constitucional y b) qué documentos jurídicos resultan aplicables para resolver los casos constitucionales.

2) De acuerdo con lo primero, la noción de Bc debe ofrecer una respuesta a la determinación de los criterios para identificar los materiales jurídicos (las disposiciones jurídicas) que pertenecen a la Constitución. De acuerdo con lo segundo, la noción de вс debe ofrecer una explicación de los criterios que hacen que documentos externos al ordenamiento constitucional sean aplicables.

3) Los asuntos relacionados con la pertenencia, aplicabilidad o el modelo de explicación de los preceptos obedecen a criterios y objetos de análisis distintos y, por tanto, a metodologías de estudio diferentes. En definitiva, la confusión entre niveles de análisis dificulta la adecuada comprensión de las relaciones entre el derecho constitucional y el derecho internacional $y$, en consecuencia, entorpece la posibilidad de una adecuada articulación entre ellos. 


\section{Referencias}

Alchourron, C. y Bulygin, E. (1974). Introducción a la metodología de las ciencias juridicas y sociales. Buenos Aires: Astrea.

Atienza, M.y Manero,J. (1996). Las piezas del derecho. Barcelona: Ariel.

Bidart, G. (1995). El derecho de la Constitución y su fuerza normativa. Buenos Aires: Sociedad Anónima Editora Comercial, Industrial y Financiera.

Bulygin, E. (1991). Algunas consideraciones sobre los sistemas jurídicos. Doxa: Cuadernos de Filosofía del Derecho, 9 (9), 257-279.

Bulygin, E. (2007). Creación y aplicación del derecho en Atria, Bullygin, Moreso, Navarro, Rodríguez y Ruiz Manero, lagunas en el derecho. Barcelona: Marcial Pons.

Colombia, Corte Constitucional (2008). Sentencia C-617.

Colombia, Corte Constitucional (2006). Sentencia C-047. M. P. Rodrigo Escobar Gil.

Colombia, Corte Constitucional (1995). Sentencia C-225. M. P. Alejandro Martínez Caballero.

Colombia, Corte Constitucional (2009). Sentencia C-228. M. P. Humberto Antonio Sierra Porto.

Friedman, B. y Smith, S. (1998). The Sedimentary Constitution. University of Pennsylvania Law Review, 147 (1), 1-90.

Gutiérrez Beltrán, A. (2007). El bloque de constitucionalidad, conceptos y fundamentos. Bogotá: Editorial Universidad Externado de Colombia.

Hart, H. (1963). The Concept of Law. Oxford.

Hart, H. (1994). The Concept of Law (2a ed.). Oxford.

Kelsen, H. (1995). Teoría general del derecho y del Estado. (Quinta reimpresión de la segunda edición). México D. F.: Universidad Nacional Autónoma de México. 
Navarro, P.y Rodríguez, J. (2014). Deontic Logic and Legal Systems. En Cambridge Introductions to Philosophy and Law. Cambridge.

Nino, C. S. (1992). Fundamentos de derecho constitucional. Buenos Aires: Astrea.

Olano, H. (2005). El bloque de constitucionalidad en Colombia. Estudios Constitucionales, 3 (1), 231-242.

Ramelli Arteaga, A. (2004). Sistema de fuentes de derecho internacional público y bloque de constitucionalidad en Colombia. Cuestiones Constitucionales: Revista Mexicana de Derecho Constitucional, (11).

Raz, J. (1990). Practical Reason and Norms. Oxford: Oxford University Press.

Rey Cantor, E. (2006). El bloque de constitucionalidad. Aplicación de tratados internacionales de derechos humanos. Estudios Constitucionales, 4 (2), 299-334.

Rodríguez J. L. y Vicente, D. E. (2009). Aplicabilidad y validez de las normas del derecho internacional. Doxa: Cuadernos de Filosofía del Derecho, (32). Recuperado el 27 de enero del 2015, de http://www.cervantesvirtual.com/obra/doxa-3/

Rodríguez,J.(2002). Lógica de los sistemas jurídicos. Madrid: Centro de Estudios Políticos Constitucionales.

Uprimny, R.(2005). El bloque de constitucionalidad en Colombia. Recuperado el 30 de enero del 2015, de http://redescuelascsa.com/sitio/repo/DJS-Bloque_Constitucionalidad\%28Uprimny\%29. pdf

Yeh,J. R.y Chang,W.C. (2008). The Emergence of Transnational Constitutionalism: Its Features, Challenges and Solutions. Penn State International Law Review, 27 (1). Recuperado el 27 de enero del 2015, de http://ssrn.com/abstract=1636163 
Este libro fue compuesto en caracteres Adobe Caslon Pro 11,2 puntos, impreso en propal de 70 gramos y encuadernado con método hot melt en octubre de 2015, en Bogotá, D. C., Colombia 


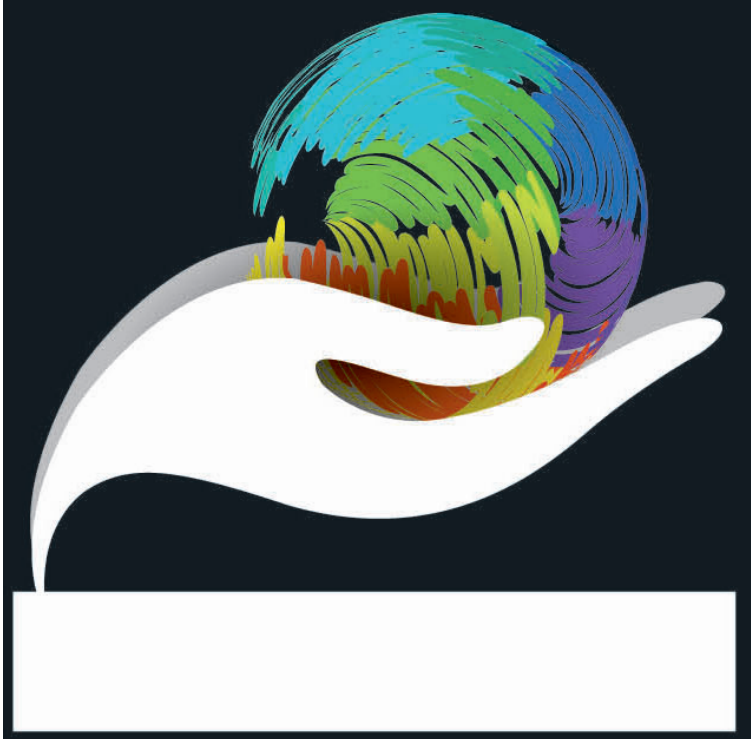

La Universidad del Rosario, por conducto de su Observatorio Legislativo y del Grupo de Investigación en Derechos Humanos de la Facultad de Jurisprudencia, se asoció con la Fundación Hanns Seidel para organizar el Foro "Protección internacional de los derechos humanos en un marco de justicia transicional". El objetivo principal del foro fue crear un espacio para hacer una reflexión, desde diversas perspectivas, alrededor de las discusiones actuales sobre derechos humanos y su protección internacional, en especial, por la coyuntura que vive nuestro país con ocasión del proceso de paz iniciado en 2012 y un eventual escenario de posconflicto derivado de éste, en el marco del derecho internacional de los derechos humanos y de la mano de expertos nacionales e internacionales en la materia.

Así mismo, tal como lo hemos venido haciendo desde hace 4 años, en el marco del Foro se realizó la V versión del Concurso Nacional de Semilleros, la cual se tituló "Discusiones contemporáneas sobre derechos humanos en el marco de la globalización", donde se buscó incentivar la participación de estudiantes universitarios interesados en temas afines a los del foro, teniendo en cuenta su importancia para el país y sus futuras generaciones. El Concurso tuvo como objeto promover la investigación formativa, enfocada hacia temáticas de especial relevancia para el país, lo cual representa un aporte que, desde la etapa de formación, los futuros profesionales de nuestra Nación hacen para el análisis y la reflexión de esos temas que tanta relevancia tienen.

Fueron seleccionadas en total 24 ponencias para participar en la ronda oral del Concurso, realizada en Bogotá los días 19 y 20 de marzo de 2015, donde se reunieron estudiantes y profesores de más de 20 universidades de todo el país. Tanto la fase oral como la escrita, contaron con la participación de profesores con altas calidades profesionales y académicas que actuaron como pares evaluadores y jurados, en una y otra fase, certificaron la calidad de las ponencias presentadas y con ello los resultados obtenidos. En el presente texto se publican las ponencias de los estudiantes ganadores del Concurso.

El objetivo es publicar las mejores ponencias ganadoras del concurso, y así seguir enriqueciendo el debate académico con la investigación realizada por parte de los estudiantes en temas de actualidad jurídica, política y social. Con el ejercicio pedagógico de este Concurso, se observaron los resultados y la importancia de la investigación formativa en las Facultades de Derecho y todas las carreras afines, y el presente libro es prueba de esto.

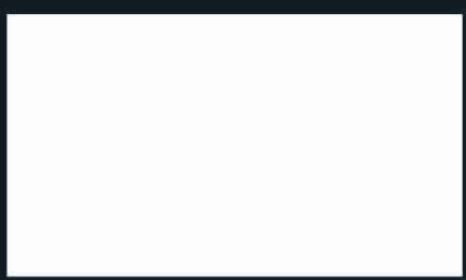

